\title{
Does Monetary Policy Affect the Central Bank's Role in Bank Supervision?*
}

\author{
Vasso P. Ioannidou ${ }^{\dagger}$
}

December, 2003

\begin{abstract}
This paper examines whether monetary policy responsibilities alter the central bank's role as a bank supervisor. The analysis focuses on the United States, where the Fed shares supervisory duties with two other federal agencies (the OCC and the FDIC). Among these three institutions, the Fed is the only one responsible for monetary policy. Hence, the Fed's supervisory behavior is compared with the behavior of the other two agencies. The comparison is made using a new panel dataset that includes all insured commercial and savings banks in the United States and all formal regulatory actions issued against these institutions during the period 1990:I- 1998:IV. The results suggest that the Fed's monetary policy responsibilities do alter its bank supervisory behavior: indicators of monetary policy affect the supervisory actions of the Fed, but do not affect the actions of the other two agencies. Moreover, the scenario in which the Fed uses bank supervision to reinforce the objectives of monetary policy is not supported by the data.
\end{abstract}

Keywords: Central Banking; Bank Supervision; Monetary Policy JEL classification: E52; E58; G21; G28

${ }^{*}$ I am grateful to Joe Peek for valuable suggestions and comments, and the Federal Reserve Bank of Boston for providing me the means and support to construct my dataset. This paper has benefited from seminar participants at Boston College, Tilburg University, the Bank of International Settlements, and the 2002 Bank Structure Conference. Any remaining errors are only mine.

${ }^{\dagger}$ Department of Economics \& CentER, Tilburg University, P.O. Box 90153, 5000 LE Tilburg, The Netherlands. Tel.: +31-13-466-3097; Fax: +31-13-466-3042; Email: V.P.Ioannidou@uvt.nl 


\section{Introduction}

In most countries, the central bank performs an important role in the management of the financial system. However, since the main task of the central bank is to maintain price stability, the assignment of other "optional tasks", such as bank supervision has been subject to debate amongst academics and policymakers for several years. For example, policymakers in the United Kingdom, Japan, and several Scandinavian countries recently removed their central bank from its role in bank supervision, while (after a long debate) the European Central Bank was given no supervisory responsibilities. In the United States, where the Federal Reserve System has only partial responsibility for the supervision of banks, there were various proposals to the Congress to consolidate all supervisory duties under a new single federal regulator, separate from the Federal Reserve.

In the literature, several arguments have been developed against and in favor of combining the two functions under the same agency. ${ }^{1}$ These arguments assume that in one way or another the central bank's supervisory duties affect monetary policy and vice versa. To date, however, there is little empirical evidence establishing the existence of such cross-effects, since data on bank supervision has been-and for the most part is stillconfidential in most countries. Given the data limitations, most of the early studies provide only indirect evidence of such cross-effects.

For example, Heller (1991) and Goodhart and Schoenmaker (1992) compare the inflation rates achieved by central banks with and without bank supervisory duties. They find that countries with central banks that have supervisory duties experience on average higher inflation rates, and interpret this as evidence supporting the "conflict of interest" hypothesis. However, higher inflation rates under a combined regime are not necessarily the result of the central bank being distracted by supervisory considerations. Moreover,

\footnotetext{
${ }^{1}$ See, for example, Di Noia and Di Giorgio (1999), Goodhart and Schoenmaker (1992) and (1995), Heller (1991), Haubrich (1996), and Peek, Rosengren and Tootell (1999). A recent paper by Barth, Nolle, Phumiwasana and Yago (2003) provides (among other things) a comprehensive review of this literature.
} 
cross-country comparisons using descriptive statistics are naturally impaired by differences across countries in the structure of their financial systems as well as differences in the timing and magnitude of their business cycles.

Instead, this paper examines whether and how monetary policy duties affect the central bank's role in bank supervision by exploiting the segmented structure of the U.S. bank regulatory and supervisory system. Specifically, all insured commercial and savings banks in the United States have one of the following agencies as their primary federal supervisor: the Federal Deposit Insurance Corporation (FDIC), the Office of the Comptroller of the Currency (OCC), or the Federal Reserve System (Fed). While the Fed's primary responsibility is to conduct monetary policy, the other two agencies have no such duty. Hence, using the FDIC and the OCC as a control group, the supervisory behavior of the Fed is compared with the behavior of the other two agencies. The analysis focuses on a particular aspect of bank supervision: the imposition of formal regulatory actions (i.e., cease and desist orders and written agreements) against banks in financial distress. This is an important aspect of bank supervision for which data can be constructed using publicly available information and for which the general procedures and criteria of imposition provide a common basis for comparison. ${ }^{2}$

In order to perform this comparison, a unique and rich dataset is created. Information collected from the formal action documents is combined with bank-level indicators of financial performance (constructed using the Call Report Data) and indicators of the aggregate and regional economy. The resulting unbalanced panel includes the "universe": all insured commercial and savings banks in the United States and all formal actions issued against these types of institutions during the period 1990:I-1998:IV.

The estimation results suggest that the Fed's monetary policy duties do alter its bank supervisory behavior. In particular, the stance of monetary policy - as captured

\footnotetext{
${ }^{2}$ The procedures of imposition of formal actions as well as how a bank's primary supervisor is determined are discussed extensively in the section on methodology.
} 
by the federal funds rate, the paper-bill spread, the Strongin measure, and other shortterm interest rates - affects the supervisory behavior of the Fed, but does not affect the behavior of the other two agencies. Since indicators of monetary policy matter only for the Fed, it is unlikely that they simply capture the effect of the business cycle. However, this possibility is formally tested in the sensitivity analysis by examining whether any of the "traditional" indicators of the business cycle (e.g., the growth rate of real GDP and the change in the national unemployment rate) affect bank supervision in the same way. It turns out that these indicators matter for all three supervisors and not just for the Fed. Moreover, similar tests show that the indicators of monetary policy do not capture differences across the three groups of banks in their exposure to interest-rate risk.

The sign on the estimated coefficient of monetary policy indicates that when the Fed tightens monetary policy, it becomes less strict in bank supervision (i.e., an increase in interest rates or a decrease in reserves is associated with a lower probability of intervention). One possible explanation is that the Fed tends to be less strict on bank supervision in order to compensate banks for the extra pressure it puts on them when it tightens monetary policy. The Fed might be interested in compensating troubled banks either because it is concerned about possible adverse effects from bank failures on its reputation or because it is concerned about possible knock-on effects. After all the Fed is responsible for maintaining the stability of the financial system and it is responsible for the supervision of some of the biggest banks in the United States.

Finally, the results also suggest that the scenario expressed by Goodhart and Schoenmaker (1992), in which the Fed uses its role in bank supervision to reinforce or protect the objectives of monetary policy, is not supported by the data. If it were, a monetary policy tightening would have been associated with a higher probability of intervention.

It is important to point out that establishing such cross-effects does not necessarily imply that the two functions should be separated or that they should be kept together. 
To answer this question would require to take into account the effect of all possible crosseffects in a theoretical framework that would allow for welfare analysis. This, however, is beyond the purpose of this paper. As mentioned earlier, the paper's main objective is to investigate whether and how monetary policy affects bank supervision when the two functions are under the same agency. This is important since it could guide theory by establishing relevant empirical facts.

The methodology and the data employed here improve upon previous studies in at least two ways. First, the paper escapes the usual criticisms of cross-sectional studies by limiting the analysis to a single country, the United States, where the segmented structure of its regulatory and supervisory system provides an ideal framework for such a study. Second, the construction and use of a unique dataset on formal actions allows a direct test of the behavior of bank supervisors.

The paper is organized as follows. Section two reviews the main arguments developed in the literature for and against the separation of the monetary and supervisory functions. Description and critical evaluation of existing empirical findings are also provided. Section three describes in detail the methodology and the data used. Section four describes and evaluates the estimation results, provides sensitivity analysis, and evaluates the economic significance of the paper's main result. Conclusions follow in section five.

\section{Theoretical Arguments and Empirical Evidence}

\subsection{Arguments Against Separation}

The major argument for combining the monetary and supervisory functions is linked to the central bank's concern for the "systemic stability" of the financial system and the protection of the payments system. Discussions focus on when it is considered appropriate for the central bank to provide lender-of-last-resort (LOLR) facilities, and whether such 
role should be accompanied by supervisory duties to reduce moral hazard.

On the grounds of moral hazard, it is appropriate to provide LOLR facilities when a bank is illiquid, but not insolvent (e.g., Bagehot, 1873). Hence, if the central bank supervises an institution, it may know more precisely whether an institution asking for credit from the LOLR is insolvent or just illiquid. However, regardless of the source of problems, the central bank may feel compelled to support failing participants to avoid systemic "knock-on" effects. Hence, to the extent that the central bank continues to operate the payments system and act as a LOLR, it is likely that it will want to maintain some regulatory and supervisory functions in order to limit moral hazard incentives and to have an intimate knowledge of the condition of banks, which can be acquired (or so it is often claimed) only through its participation in the supervisory process. ${ }^{3}$

Goodhart and Schoenmaker (1995), using a cross-country micro-dataset, found that countries where central banks are involved in supervision have on average fewer bank failures. As they point out, this finding has no welfare implications, since it is not clear whether the cost of a bank failure compensates for the efficiency loss in resource allocation and other costs linked to the bail out. Hence, they went on to examine the method adopted to deal with failing banks (i.e., rescue-package, take-over by other banks, special administration, and liquidation) and the resulting choice of funding (i.e., central bank, commercial banks, deposit insurance, government, no external funding). For the method of dealing with a failing bank they found no significant difference between the combined and separated regimes. Instead, they found that less government and more commercial bank funds are involved in countries with combined regimes. However, an

\footnotetext{
${ }^{3}$ This argument assumes that it is not possible for a third party, responsible for bank supervision, to transfer information effectively to the LOLR. This assumption is clearly debatable. However, it seems more plausible during periods of financial instability, since the speed and the degree with which the condition of an institution deteriorates is significantly higher during periods of financial instability. Moreover, it is in "bad" times that institutions are more likely to "cook" their books and hide their true condition. Hence, under these circumstances direct supervision could help deliver the essential information on time.
} 
important concern regarding these results is that they are based on simple descriptive statistics, while they involve comparisons across a rather heterogeneous set of countries. ${ }^{4}$

Peek, Rosengren and Tootell (1999) raised a novel argument for combining the monetary and supervisory functions. They argued that information obtained from bank supervision could improve the accuracy of economic forecasting, and thus help the central bank to conduct monetary policy more effectively. In particular, problems in the banking sector may serve as an early indicator of deteriorating macroeconomic conditions. ${ }^{5}$ Peek, Rosengren and Tootell (PRT) found that supervisory information can and does help the Fed to conduct monetary policy more effectively. In particular, they found that confidential information on the health of the banking system (i.e., CAMEL ratings) is useful in predicting inflation and unemployment, but is not used by private forecasters or by the Fed itself in its forecasts. Although, the Fed does not seem to make systematic use of this information in its Greenbook forecasts, the authors found that this confidential information is taken into account when setting monetary policy (i.e., it is found to affect the votes of the Federal Open Market Committee members).

A more recent study by Feldman et al. (2003) reexamined the findings by PRT by extending their in-sample analysis to an out-of-sample framework. The authors found that the supervisory information used by PRT does not improve the out-of-sample forecast of inflation, while it improves the forecast of unemployment. However, the maximum improvement in forecasting unemployment was 0.17 percentage points, which might be too small to affect policymakers. To examine whether this increase in forecast accuracy would alter monetary policy, the authors estimated two forward-looking policy rules: one using the Greenbook forecasts and another using the forecast produced with the super-

\footnotetext{
${ }^{4}$ The sample includes Australia, Austria, Belgium, Canada, Denmark, Finland, France, Germany, Greece, Hong Kong, Ireland, Italy, Japan, Luxembourg, Netherlands, New Zealand, Norway, Portugal, Spain, Sweden, Switzerland, United Kingdom, United States, and Venezuela.

${ }^{5}$ For example, supervisory information could provide advance notice of changes in bank lending behavior to the extent that the "lending channel" of monetary policy is operative (see, for example, Bernanke and Gertler, 1995; Hubbard, 1995; and Kashyap, Stein and Wilcox, 1993).
} 
visory information. The second rule produced a federal funds rate that was closer to the optimal funds rate, but only by four to twelve basis points.

Even if one believes that supervisory information is indeed valuable for forecasting key macroeconomic variables, this evidence does not in itself establish that the Fed should be the supervisor. The Fed could simply request this information from the agency doing the supervision. PRT argue that effective use of this information may be very difficult in practice. In particular, the assessment of a bank's health and the information used may depend on the objective function of the agency doing the supervision. Differences in objectives could lead to the collection and emphasis of different information. It may also affect the way CAMEL ratings are assigned. ${ }^{6}$ Thus, in order to effectively use the bank supervisory information, the Fed should not only know the aggregate ratings, but whether and for which institutions forbearance is occurring. PRT argue that the latter implies a direct supervisory role for the central bank. While all these arguments are entirely plausible, others are not fully convinced that direct supervision is necessary for effective and timely transfer of information (see Bernanke, 2001).

\subsection{Arguments for Separation}

The most common argument for separating monetary policy responsibilities from bank supervision is that the combination of the two functions may lead to a "conflict of interest" between the monetary authority, that desires higher interest rates (e.g., to fight inflation or to maintain an exchange rate peg), and the supervisory authority, that is concerned about the adverse effects of higher interest rates on the solvency and profitability of the banking sector. Similarly, it is easy to imagine situations where officials in charge of monetary policy may want to rescue a bank because of systemic stability concerns, while

\footnotetext{
${ }^{6}$ For example, during the Third-World debt crisis, some banks that were perceived as "too big to fail" may have received better CAMEL ratings than their true condition warranted.
} 
officials responsible for supervision may want to close it to avoid moral hazard.

A more general point made by Goodhart and Schoenmaker (1992) is that the cyclical effects of micro (regulatory) and macro (monetary) policy tend to be in conflict. Monetary policy is usually countercyclical, while the effects of regulation and supervision tend to be procyclical, offsetting to some extent the objectives of monetary policy. ${ }^{7}$ In particular, during periods of economic slowdown, the financial condition of banks is usually deteriorating. In this case, the bank's supervisor steps in and applies pressure on the institution to improve its condition. However, the bank's implementation of supervisory requirements results in even tighter credit during an economic recession. ${ }^{8}$ Following this line of argument, one might expect the central bank to use its supervisory role to complement monetary policy (i.e., to be less strict in supervision when monetary policy is expansionary and vice versa).

However, these conflicts are genuine and are not likely to be eliminated by institutional rearrangements. Hence, the key question is which institutional setup would resolve these conflicts in the most efficient way for the society at large. Some researchers argue that internalizing conflicting goals within a single agency may result in a more efficient resolution because of lower frictions in deciding and implementing policies and because of enhanced accountability (e.g., Briault, 1999; and Llewellyn, 1999).

From an empirical perspective, it is very difficult to document whether (or the extent to which) interest rates were kept lower than they would have been on the basis of purely monetary considerations, since discussions are usually internalized within the central bank. However, there were a number of cases where it was argued that interest rates were

\footnotetext{
${ }^{7}$ For example, the slow recovery from the 1990 U.S. recession was attributed by many researchers to a dramatic decrease in the supply of bank loans caused by increased capital requirements and more stringent regulatory practices (see Bernanke and Lown, 1991; Berger and Udell, 1994; Berger, Kashyap and Scalise, 1995; Hancock, Laing and Wilcox, 1995).

${ }^{8}$ Formal regulatory interventions have been found to have an immediate negative impact on new lending. For example, Peek and Rosengren (1995) found that banks under formal actions decrease new lending by 1.9 percent per quarter.
} 
held down because of concerns about the stability of the financial sector. ${ }^{9}$ For example, during the 1980s and the beginning of the 1990s, the U.S. interest rates were kept low because of the severe problems of the Savings and Loan Associations (see Vittas, 1992). Moreover, it is widely believed that in 1982 Chairman Volcker was under pressure to abandon the non-borrowed reserve scheme because of the effects of interest rate volatility on the debt of less developed countries and the solvency of major U.S. banks.

To test whether conflicting goals affect the performance of central banks with supervisory responsibilities, Heller (1991) and Goodhart and Schoenmaker (1992) compared the inflation rates achieved by central banks with and without supervisory duties. They found that countries whose central banks do not have supervisory duties have on average lower inflation rates. However, as Heller (1991) pointed out "it may well be that independent central banks are better in attaining the goal of price stability and that these independent banks do not tend to have supervisory responsibilities". It turns out that even after controlling for central bank independence, central banks without supervisory duties achieve lower inflation rates (Di Noia and Di Giorgio, 1999).

Combining the two functions may also involve reputation risks for the central bank. If the central bank is responsible for bank supervision and bank failures occur, the public perception of its credibility could be adversely affected (e.g., Bank of England and the failure of BCCI in 1991). Moreover, the public and politicians often blame the regulatory authority for the crises that do occur, but do not give credit to regulators for crises that are successfully prevented. Hence, it has been argued that the reputation of the central bank is more likely to suffer, than to benefit, from bank supervision.

\footnotetext{
${ }^{9}$ The effect of high interest rates on the profitability of the banking system depends on how long interest rates are held high and on the balance sheet structure of the banking system (i.e., the repricing and maturity structure of the asset and liability sides of their balance sheets).
} 


\section{The Empirical Analysis}

\subsection{Methodology}

Does the central bank's responsibility for monetary policy alter its behavior as a bank supervisor? This question can be addressed by taking advantage of the segmented structure of the U.S. bank regulatory system. All insured commercial and savings banks in the United States are primarily supervised by one of the following federal agencies: the FDIC, the OCC, or the Fed. Due to historical reasons, the identity of a bank's primary federal supervisor depends on its charter (national or state) and on whether it chooses to be a member of the Fed or not. Specifically, a nationally-chartered bank is supervised by the OCC, while a state-chartered bank has the Fed as its primary supervisor if it chooses to be a member of the Fed and the FDIC otherwise. Among the three agencies, the Fed is the only one responsible for monetary policy. Hence, the Fed's behavior as a bank supervisor is compared with the supervisory behavior of the other two agencies.

The comparison focuses on a particular aspect of bank supervision: the issuance of FAs against financially troubled institutions on the basis of "safety-and-soundness". In general, the term formal action- as opposed to informal action- refers to actions that are legally enforceable. FAs include cease and desist orders, written agreements, prohibitionand-removal orders, civil money penalties, and prompt-corrective-action directives. Here, the analysis is confined to cease and desist orders (C\&Ds) and written agreements (WAs), which are usually issued against banks with serious financial problems. ${ }^{10}$

Prohibition-and-removal orders and civil money penalties are not included because they are usually issued against individuals affiliated with an institution because of violation of laws and regulations and not because the financial condition of the institution has been deteriorating. ${ }^{11}$ Prompt-corrective-actions are also not used because they are

\footnotetext{
${ }^{10}$ From now on, the term FA will be used to refer to C\&Ds and WAs only.

${ }^{11}$ When the illegal actions of the individuals are such that endanger the safety-and-soundness of the
} 
automatically triggered by deficient capital levels under the Prompt Corrective Action guideline. Thus, they can not be used to compare the behavior of the Fed with the other two agencies. What is needed is actions for which there are some general procedures and criteria of imposition, but these procedures are not automatic and thus allow for some degree of discretion on the bank supervisors. C\&Ds and WAs are ideal for this matter.

Supervisors conduct on-site examinations to determine whether bank practices are consistent with sound banking operations. When an institution is discovered to have serious financial problems, its primary supervisor can intervene by imposing a $C \& D$ or WA to force the institution to correct the problems. ${ }^{12}$ This type of intervention is based on the absolute and relative health of the institution. While examiners use various banklevel indicators to evaluate the condition of a bank, the same indicators may or may not trigger intervention, depending on the size of the bank and the condition of its economic environment. As the economic environment (both national and regional) deteriorates, a bank faces a greater probability of failure, since the health of its borrowers and the value of any collateral securing loans deteriorate. Bank size may also be relevant. In the presence of asymmetric information, larger banks can absorb more risk, since it is easier for them to raise additional funds if needed (due to reputation effects or to "too-big-tofail" subsidies). Moreover, big banks are better able to diversify their loan portfolios.

Thus, the probability of getting a FA is modeled using a probit model:

$$
P\left(Y_{i, t}=1\right)=F\left(\beta^{\prime} X\right)+\varepsilon_{i t},
$$

where $F(\cdot)$ is assumed to be the standard normal distribution. ${ }^{13} Y_{i, t}$ is equal to one if the supervisor imposed a FA on bank $i$ at time $t$, and is equal to zero otherwise. The matrix $X$ includes indicators of the condition of bank $i$ at time $t$ and $t-k$, indicators of the prospects institution, a C\&D or a WA is issued against the institution as well.

${ }^{12}$ Since FAs are legally enforceable with civil monetary penalties for noncompliance, they are viewed as the most serious actions available to supervisors, short of closing the bank.

${ }^{13}$ The estimation results are qualitatively the same if a logit model is used. 
of the economic environment in which the bank operates, and a bank size indicator. In addition, supervisory agency dummy variables are used to account for the possibility of systematic differences across agencies either in supervisory standards or in the quality of banks supervised. The paper's central hypothesis is tested using interaction terms between a monetary policy indicator and the supervisory agency dummy variables. ${ }^{14}$

A few comments are in order. First, following Peek and Rosengren (1995), time $t$ refers to the exam date that resulted in the imposition of a FA and not to the date that the action became effective (i.e., the sign date). If time $t$ was referring to the sign date, the analysis would capture a different condition (most probably improved) from the one that triggered intervention by the bank's supervisor. In particular, supervisors decide to issue a FA based on the information they obtain during an examination. However, FAs become effective at least 60 to 90 days after the exam date and many over a year later. During this interim period, the bank knows that a FA is going to be issued against it. Hence, it is expected to start improving its condition even before the action is signed.

Second, $Y_{i, t}$ does not include observations of banks that at time $t$ were already under a FA. In particular, once a bank is under a FA, its subsequent observations until the action is terminated are dropped. If a bank is already under a FA, it can not receive another action of the same type before the first one is terminated.

\subsection{Data Description}

A pooled time-series and cross-sectional panel of all FDIC-insured commercial and savings banks in the United States is constructed in order to estimate equation (1). In particular, information collected from the FA documents is combined with bank-level indicators of financial performance and indicators of the aggregate and regional economy.

\footnotetext{
${ }^{14}$ In the sensitivity analysis, a separate regression is estimated for each agency in order to examine the robustness of the results when all coefficients are allowed to differ across the three supervisors.
} 


\subsubsection{Formal Actions}

The dataset covers the period 1990:I-1998:IV. Data availability regarding the dependent variable $Y_{i, t}$ determines the sample's starting point. Specifically, the date of the examination that resulted in the imposition of a FA is necessary for generating $Y_{i, t}$. These exam dates are reported in the FA documents, which have been disclosed only since the end of 1989. In particular, the Financial Institutions Reform, Recovery, and Enforcement Act (FIRREA) of 1989 made public all C\&Ds signed after August 9, 1989, while the Crime Control Act of 1990 requires disclosure of all WAs signed after November 29, 1990.

Even if WAs signed prior to November 29, 1990 are not available, the sample begins in 1990:I in order to take advantage of C\&Ds imposed during 1990. The estimation results would have been biased if banks that received a WA appeared in the data as if they did not (i.e., $Y_{i, t}$ equals 0 when it should equal 1 ). For this reason, termination documents are used to identify banks that received a WA any time between January 1 and November 29, 1990. These banks are then dropped for the period between 1990:I and the termination of the action. ${ }^{15}$ The same procedure is used to identify and eliminate any bank that entered the sample period with a FA issued prior to August 9, 1989. Finally, the sample includes FAs that were clearly related to deteriorating financial condition and not only to some violations of laws and regulations. ${ }^{16}$

Table 1 reports the number of FAs issued during the 1990:I-1998:IV period. Interestingly, 86\% of the total 1013 FAs are imposed between 1990 and 1993, when the banking industry faced one of its worst crises since the Great Depression. The bottom panel of

\footnotetext{
${ }^{15}$ The termination documents include the date the action was imposed (i.e., the sign date) and the date it was terminated. Unfortunately, the termination documents do not include examination dates.

${ }^{16}$ Actions issued because of deteriorating financial condition are easy to identify when reading the actual documents. A typical quote from the type of actions included is: "Bank ordered to cease and desist from such unsafe and practices as operating with an excessive volume of adversely classified assets; engaging in hazardous lending and lax collection practices; operating with inadequate equity capital; operating with inadequate loan and lease loss allowances;..." (Docket no.: FDIC-90-106b). In general, when the problems are of the nature described above, the actions include specific guidelines of how to restore the problems and prohibit the bank from paying dividends.
} 
Table 1 shows the percentage of banks under each supervisor that received a FA at each point in time. It seems that banks under the FDIC are less likely to receive a FA than banks under the FED or the OCC and this is true for every year in the sample. However, the comparison between the FED and the OCC varies over time.

\subsubsection{Bank-Level Data}

Bank-level indicators of performance for all insured commercial and savings banks in the United States are constructed using the Consolidated Reports of Condition and Income (Call Reports), available from the Federal Reserve Bank of Chicago. In order to create consistent time-series variables, this dataset involves a number of challenges (e.g., dealing with mergers, de novos, "shell" banks, and changes of definitions over time). ${ }^{17}$

The indicators used to capture the health of an institution cover the main areas in which examiners base their evaluations. Table 2 provides a list of indicators as well as definitions and notation. The specific ratios are motivated from other studies on FAs (e.g., Peek and Rosengern, 1995 and 1997) as well as studies that use Call Report data to capture the supervisory assessment of bank condition (e.g., Berger, Kyle and Scalise, 2000). For example, it is known that supervisors view capital adequacy as a key element in reducing bank risks. To evaluate capital adequacy, regulators look at three capital ratios: tier 1 capital to risk-weighted assets, total capital to risk-weighted assets, and tier 1 capital to average assets. The higher these ratios, the lower the probability of receiving a FA, other things equal. It should be pointed out that all capital ratios were constructed as to exactly equal the measure generated by each of the three supervisors at each point in time, following all the changes in regulation during the sample period.

The asset quality of an institution is evaluated with respect to the concentration of its loan portfolio, the severity of its credit-risk problems, the adequacy of its loan loss

\footnotetext{
${ }^{17}$ See the Data Appendix for more details on the methods used to deal with these problems.
} 
reserves, and its exposure to interest-rate risk. In particular, ratios of portfolio concentration in risky types of loans reflect potential exposure to excess risk. For instance, if a particular sector of the economy is under stress (e.g., the real estate sector), then banks with a loan portfolio that is highly concentrated in that sector will face an increased probability of failure. The ratio of nonperforming loans to total loans provides an indicator of current and future credit-risk problems, while the ratio of other real estate owned to total loans reflects past problems with credit-risk. ${ }^{18}$ Hence, the higher these ratios, the higher the probability of receiving a FA.

Gap variables (scaled by total assets) are included to capture a bank's short-run exposure to interest-rate risk. Following Peek and Rosengren (1997) and Simons (1995), the gap variables are measured as the absolute value of the difference between assets and liabilities (i.e., loans plus securities minus deposits) maturing or repricing within a given interval. The intervals used are: up to three months and three months to a year. The higher these ratios are, the higher the probability of a FA. Unfortunately, the information that is necessary in order to construct these gap variables is not reported by a large number of banks. Hence, including the gap variables in the estimation results in a loss of about 32 percent of the total number of observations. For this reason, some of the key specifications are also estimated without the gap variables.

Earnings ratios such as the return on average assets (or on average equity) captures the ability of an institution to supply additional capital and meet possible losses. Hence, the higher are these ratios, the lower the probability of receiving a FA. A bank's liquidity is of particular importance when a bank becomes troubled. Deposit withdrawals and the reluctance of other institutions to expose themselves to counterparty risk through transactions with a troubled bank can lead to increased liquidity requirements. Hence,

\footnotetext{
${ }^{18}$ The nonperforming loans series is calculated as loans that are 90 or more days past due plus loans that are in a nonaccrual status. The other real estate owned series is composed of real estate collateral from foreclosed loans.
} 
the higher the ratio of liquid assets to total assets, the lower the probability of receiving a FA. ${ }^{19}$ In contrast, unstable or highly liquid deposits (e.g., brokered deposits) increase the probability of a liquidity problem, and thus increase the probability of a FA.

Under off-balance sheet activities two ratios are included. The first ratio, interest rate derivatives to total assets, is used in order to capture the extent to which an institution is speculating or hedging against interest rate risk using off-balance sheet derivatives. The measure includes swaps, futures, and option contracts (both written and purchased). In general, derivatives could increase or decrease the probability of a FA, depending on whether the institution is using them for speculation or hedging. The second ratio, non-interest income to total income, is included in order to capture the size of a bank's off-balance sheet activities. In recent years, there were concerns that banks are using off-balance sheet activities to engage in regulatory capital arbitrage.

Table 3 compares the average risk profile of three groups of banks: i) banks not under a FA, ii) banks at the exam date that resulted in a FA, and iii) banks under a FA at the time of the termination of the action. As expected, banks have a significantly worse risk profile at the time of the exam that resulted in a FA compared to banks that are not under a FA. In particular, they are less well capitalized, less profitable, have a less diversified loan portfolio, and have more liquid deposits. Moreover, a higher share of their loans is nonperforming and they have a lower loan loss reserves ratio. However, when the action is terminated, their average risk profile is significantly improved.

\subsubsection{Macro-Level Data}

A crucial ingredient for estimating equation (1) is a good indicator of the stance of monetary policy. Unfortunately, there is no consensus in the literature as to which variable

\footnotetext{
${ }^{19}$ Liquid assets are calculated as the sum of interest-bearing balances due from depository institutions, average federal funds sold, securities purchased under agreement to resell, assets held in trading accounts (net of revaluation gains), and the market value of securities less the value of pledged securities.
} 
is the best indicator. Over the years, a number of indicators have been proposed, such as the federal funds rate, the portion of non-borrowed reserves growth that is orthogonal to total reserves growth (known as the Strongin measure), the paper-bill spread, the Boschen-Mills index, and other short-term interest rates (e.g., three or six month treasury bill rates, three or six month commercial paper rates, etc.). ${ }^{20}$

Among the various indicators, the federal funds rate is the one that is most widely used in the empirical literature since it is found to perform well for most periods. As Bernanke and Mihov (1998, pp. 899) point out, "For practitioners looking for a simple indicator of policy stance, our results suggest that using the federal funds rate prior to 1979; nonborrowed reserves from 1979 to 1982, and either the funds rate or Strongin's measure in the most recent period, will give reasonable results." Since the sample is limited to the $1990 \mathrm{~s}$, the funds rate is used as the main indicator of the stance of monetary policy. ${ }^{21}$ However, as discussed in the sensitivity analysis, the results are robust to many other indicators that are widely used in the literature, including the Strongin measure.

Indicators of the economic environment are used to control for the effect of the business cycle on the probability of receiving a FA. Specifically, real Gross Domestic Product, and national and state unemployment rates are taken respectively from the National Income and Product Accounts and the Bureau of Labor Statistics. Finally, a set of regional dummy variables, based on census regions, is included in the estimations to account for systematic differences across regions.

\footnotetext{
${ }^{20}$ See Bernanke and Mihov (1998) for an extensive literature review on measuring monetary policy and for further references.

${ }^{21}$ The Federal Reserve Board of Governors releases the funds rate at both daily and monthly frequencies, among others. The monthly series consists of the average of the daily figures during each month. Here, the monthly series is converted into a quarterly series using the observation for the last month of each quarter. In this case, "spikes" in the funds rate (which happen occasionally for a day or two due to temporary reserve conditions) are averaged out during the month.
} 


\section{Estimation Results}

Table 4 provides estimation results for five different specifications of equation (1). Column (1) reports a benchmark regression, which is similar to what can be found in the literature. $^{22}$ It includes bank-level indicators of financial performance, a bank size indicator, dummy variables for the bank's primary federal supervisor, as well as regional and quarterly time dummies. Almost all estimated coefficients on indicators of bank health and size are statistically significant and have the expected signs.

The estimated coefficients on the supervisory agency dummies are significant, suggesting that there are systematic differences across supervisors (in toughness, standards, or even in the quality of banks supervised) which are not fully captured by other righthand-side variables. Specifically, the estimated coefficient on the OCC dummy variable is positive, suggesting that banks supervised by the OCC are more likely to receive a FA than are banks supervised by the Fed, other things equal. In contrast, the negative estimated coefficient for the FDIC dummy variable indicates that banks supervised by the FDIC are less likely to receive a FA than are banks supervised by the Fed.

Regional and quarterly time dummies are used to capture the effects of the economic environment on the probability of receiving a FA. However, these variables account not only for the business cycle, but also for anything else that varies systematically across geographical regions and time. Hence, when an indicator of monetary policy is introduced in columns (2)-(5), the quarterly dummy variables are replaced by indicators of the business cycle such as the growth rate of real GDP, the change in the rate of national unemployment, and the difference between state and national rates of unemployment.

Specifically, in column (2) the federal funds rate is added in order to examine whether the stance of monetary policy affects the probability of supervisory intervention in trou-

\footnotetext{
${ }^{22}$ In particular, Peek and Rosengren (1995 and 1997) examine the determinants of FAs using a similar framework, but without considering any monetary policy aspect or differences across supervisors. The estimation results, reported in column (1), are consistent with their findings.
} 
bled banks. The estimated coefficient on the federal funds rate is negative and insignificant. Hence, it seems that after controlling for the health of an institution, the business cycle, the bank size, the type of FA, and the bank's primary supervisor, the probability of a FA does not depend on the stance of monetary policy.

However, when in column (3) the federal funds rate is interacted with supervisory dummy variables to allow for differential effects across supervisors, an interesting result emerges. Monetary policy affects the supervisory actions of the Fed, but does not affect the actions of the other two agencies. In particular, the estimated coefficient on the federal funds rate for the Fed is negative $(-.0728)$ and significant at $1 \%$ confidence level. In contrast, the estimated coefficients for the OCC and the FDIC are highly insignificant and approximately equal to zero ( -.0048 for the OCC and -.004 for the FDIC). Similar results are obtained in column (4) when the growth rate of real GDP (one of the control variables of the business cycle) is replaced by the annual change in the rate of national unemployment. ${ }^{23}$ The same result is obtained in column (5) when the gap variables are dropped and the model is estimated using many more observations.

The negative sign on the coefficient of the federal funds rate suggests that when the Fed increases the funds rate, it becomes less strict in its bank supervisory role. One possible explanation is that the Fed tends to be less strict on supervision in order to compensate banks for the extra pressure it puts on them by increasing the funds rate. An increase in the funds rate can be thought as an extra tax on banks for at least two reasons. First, it increases the opportunity cost of holding non-interest-bearing reserves. Second, it pushes banks towards more costly forms of finance. Specifically, a contractionary monetary policy reduces the amount of reserves in the economy and thus forces banks to rely more heavily on sources of finance that are not subject to reserve requirements (e.g., equity). Given capital market imperfections, these alternative sources

\footnotetext{
${ }^{23}$ The growth rate of real GDP is never included in the same regression with the annual change in the rate of national unemployment since the two variables are highly correlated.
} 
of finance are typically more expensive since they are not subject to deposit insurance. Moreover, they are even more expensive for banks with serious financial problems that just received a FA; as mentioned earlier, FAs are publicly available.

FAs can be viewed as some kind of a ultimatum to financially troubled institutions to immediately deal with their problems. Forcing these banks to deal with their problems means that they will either manage to correct them (and become healthy again) or that they will be forced to close. In fact, almost all FAs require banks to increase their provisions for bad loans and to raise their capital ratios within a limited period of time. Clearly, this might be very costly for banks with serious financial problems, but it is even more costly when monetary policy is contractionary, since banks must rely even more on more expensive sources of finance (e.g., Kashyap and Stein, 2000; Stein, 1998).

Given this additional pressure, the Fed might be interested in compensating troubled banks either because it is concerned about the adverse effects of bank failures on its reputation (in conducting monetary policy) or because it is concerned about possible knock-on effects. After all the Fed is responsible for maintaining the stability of the financial system and it is responsible for the supervision of some of the biggest banks in the United States. More generally, it seems that the Fed's behavior as a bank supervisor is altered by macroeconomic considerations related to its additional responsibilities, while the behavior of the other two agencies that do not have these responsibilities is not.

Finally, it should be pointed out that the negative sign on the coefficient of the federal funds rate also indicates the Fed is not using its bank supervisory role to reinforce the objectives of monetary policy. If it were, the funds rate would enter with a positive sign (i.e., the Fed would relax its supervision when monetary policy is expansionary).

Although the discussion so far has focused on the main question of interest- whether the Fed's responsibilities for monetary policy affect its behavior in bank supervisionTable 4 contains other interesting findings. In all specifications, most of the indicators of 
bank health are statistically significant and enter with the expected sign (i.e., the better the financial health of a bank, the lower the probability of intervention).

For example, the estimated coefficient on Tier 1 capital to average assets (Tier $1 / A v A)$ is negative, indicating that the higher a bank's capital ratio, the lower the probability of a FA. Moreover, it seems that examiners base their evaluations not only on the capital position of a bank at a certain point in time, but also on its recent trend. In fact, the coefficient on the annual change of Tier $1 / A v A$ is negative, suggesting that the probability of a FA decreases as the bank's capital position improves. Instead, the coefficient on Tier 1 capital to risk-weighted assets $(\operatorname{Tier} 1 / R W A)$ is not statistically significant.

Ratios of portfolio concentrations in high-risk types of loans reflect potential exposure to excessive risk. In fact, the ratios of real estate loans to total loans $(R E L / L)$ and commercial and industrial loans to total loans $(C \& I / L)$ enter with a positive sign. The estimated coefficient on other real estate owned to total loans $(O R E O / L)$ is positive, since it captures past problems with credit-risk. Nonperforming loans to total loans $(N P L / L)$ provide some indication of current and future loan portfolio problems with credit risk and therefore increase the probability of a FA. In general, the ratio of loan loss reserves to total assets $(L L R / A)$ could enter either with a negative or a positive sign. A negative sign should be expected if $L L R / A$ captures the degree to which an institution takes precautions against future loan losses. However, a high $L L R / A$ ratio could also be an indicator of greater than normal problems with nonperforming loans and therefore increase the probability of supervisory intervention. Here, $L L R / A$ enters with a positive sign, but it is not statistically significant. Instead, Peek and Rosengren (1995) found that $L L R / A$ have a statistically positive effect on the probability of a FA. The gap variables, GAP1 and GAP2, enter with a positive sign, but are not statistically significant. ${ }^{24}$ This

\footnotetext{
${ }^{24}$ Similar results were obtained using alternative definitions of gap variables. For example, GAP1 and $G A P 2$ were constructed without taking the absolute values. In addition, in order to capture the effects on the bank's profits, the gap variables (without the absolute values) were multiplied by the change in the interest rates as follows: $G A P 1 / A_{t} \cdot\left(F F u n d s_{t+1}-F F u n d s_{t}\right)$ and $G A P 2 / A_{t} \cdot\left(F F u n d s_{t+4}-F F u n d s_{t}\right)$.
} 
result is consistent with the findings of Peek and Rosengren (1997).

Earnings ratios, such as the return on average assets $(R / A v A)$, indicate the ability of an institution to supply additional capital and meet possible losses. Thus, the higher is $R / A v A$, the lower the probability of receiving a FA. Instead, the higher the ratio of loan loss provisions to average assets $(L L P / A v A)$, the higher the probability of a FA since it indicates lower bank profitability and credit risk problems.

The higher the liquidity of an institution the lower the probability of short-term liquidity problems. Hence, the higher the ratio of liquid assets to total assets $(L A / A)$, the lower the probability of receiving a FA. However, unstable or highly liquid deposits, such as brokered deposits $(B K D / A)$, increase the probability of liquidity problems and therefore increase the probability of supervisory intervention. This coefficient, however, is statistically significant only for the specification where the gap variables are dropped and the model is estimated using many more observations.

Bank size (log Assets) is highly significant and enters with a negative sign, which is consistent with at least two interpretations. It is possible that supervisors intervene less in bigger banks simply because big banks can absorb more risk (e.g., better access to capital markets) or because big banks are better able to "capture" their supervisors.

Under off-balance sheet activities, the ratio of interest rate derivatives to total assets (Derivatives $/ A$ ) is statistically significant and enters with a positive sign, suggesting that banks may be using derivatives for speculation or that they are not hedging their risk perfectly. Finally, the ratio of non-interest income to total income (NII/TII), used in order to capture the size of off-balance sheet activities, is highly significant only when the gap variables are dropped.

The estimation results from these specifications are not reported, but are available upon request. 


\subsection{Sensitivity Analysis}

Although the results presented in Table 4 are consistent with the hypothesis that the Fed's monetary policy responsibilities alter its behavior as a bank supervisor, they are also consistent with two alternative interpretations.

First, it is possible that the federal funds rate captures some differential response of supervisors with respect to the business cycle. To investigate this possibility, traditional indicators of the business cycle are interacted with the supervisory dummy variables. In the first column of Table 5, the growth rate of real GDP is interacted with the FDIC, the OCC, and the FED dummy variables. The results show that the growth rate of real GDP matters for all three supervisors and not just for the FED. In addition, hypothesis tests reject any differential effect across supervisors with respect to the business cycle (i.e., the estimated coefficients on the interacted terms are not statistically different from each other). The same is true for the annual change of the national rate of unemployment in column (2). Since none of the business cycle indicators exhibits the characteristics of the estimated coefficients on the federal funds rate, it seems unlikely that the paper's main result is due to some differential response to the business cycle.

Second, it is also possible that the funds rate captures differences across the three groups of banks in their exposure to interest-rate risk. In particular, it is possible that banks under the Fed are adversely affected by changes in interest rates, while banks under the OCC and the FDIC are not affected (or they even gain) from changes in interest rates. For example, if a bank has more liabilities than assets maturing or repricing within a given period, it would be adversely affected by an increase in interest rates. Instead, if a bank has more assets than liabilities maturing or repricing within a given period, it would actually gain from an increase in interest rates. To investigate this possibility, indicators of exposure to interest-rate risk are interacted with the supervisory dummy variables. In column (3) of Table 5, GAP1/A is interacted with the supervisory dummy variables. The 
results show that $G A P 1 / A$ is not statistically significant for any of the three supervisors. The same is true for $G A P 2 / A$ in column (4). Instead, in column (5) the coefficient on derivatives/A is statistically significant for all three supervisors (and not just for the Fed), while hypothesis tests show that the coefficient for the OCC is statistically different from the other two supervisors. However, since none of these indicators exhibits the characteristics of the estimated coefficient on the funds rate, it seems unlikely that the paper's main result is simply due to different exposures to interest-rate risk.

More generally, constraining differences to show up in few coefficients could produce misleading results (i.e., it could cause some coefficients to appear different, when the differences are in fact due to other coefficients that are forced to be the same). To investigate this possibility, a separate regression is estimated for each supervisor. The results, reported in Table 6, show that even when all coefficients are allowed to differ the indicator of monetary policy is still significant only for the Fed. ${ }^{25}$

Finally, it should be pointed out that the results presented so far are robust to many other indicators of monetary policy that are widely used in the literature. In particular, the following alternative indicators were tried: the paper-bill spread, the Strongin measure, the Boschen-Mills index, and other short-term interest rates (e.g., the three or six month treasury bill rates and the three or six month commercial paper rates). The results go through for all indicators, except for the Boschen-Mills. ${ }^{26}$ However, this is not surprising since during the sample period the correlations between this index and all other indicators of monetary policy are quite low (from 0.24 to 0.42 ). This, however, is specific to the post-1990s period. Prior to the 1990s these correlations are much higher (from 0.5 to 0.74 , depending on the sub-period). Most studies that use these alternative indicators of monetary policy find that they yield similar results (e.g., Bernanke and

\footnotetext{
${ }^{25}$ Similar results are obtained when the gap variables are interacted with the change in the funds rate (e.g., GAP1/At $\left.*\left(F F u n d s_{t+1}-F F u n d s_{t}\right)\right)$. Due to space constraints these results are not reported, but are available upon request.

${ }^{26}$ Due to space constraints the results are not presented in the paper but available upon request.
} 
Mihov, 1998; Campello, 2002; Kashyap and Stein, 2000). However, these studies use a sample that starts much earlier (in the 1960s, 1970s, or in some cases in the 1980s), when the correlations between the Boschen-Mills and the other indicators are much higher.

All evidence suggests that the central bank's monetary policy responsibilities do alter its role in bank supervision, at least for the United States during the sample period. Note that this interpretation assumes that the causation runs from monetary policy to supervision and not vice versa. In other words, the independent variable that captures the stance of monetary policy (i.e., the federal funds rate), is indeed exogenous to the dependent variable (i.e., the probability of a FA in bank $i$ at time $t$ ). Since the analysis uses a micro dataset, it is not unreasonable to argue that intervention in a single bank could not be causing changes to a national variable such as the funds rate. Moreover, if the reverse causation was true, the federal funds rate would have been significant for all banks and not just for those supervised by the Fed (i.e., it would have been the health of all banks in the economy affecting the Fed's choice of interest rate).

\subsection{Economic Significance and Goodness of Fit}

Table 7 reports the marginal effect of each regressor in order to evaluate the economic significance of the paper's main result. ${ }^{27}$ The first two columns report the percentage change in the probability of a FA because of a 100-basis points increase in each one of the regressors, keeping all other variables at their mean values. For robustness, columns (1) and (2) report two alternative specifications: one where the gap variables are included and one when they are not. It turns out that the results are qualitatively the same.

In general, bank capital, nonperforming loans, loan loss provisions, bank size, and business cycle indicators are among the most important determinants of the probability

\footnotetext{
${ }^{27}$ The marginal effects reported in Table 7 are based on the more general specifications of Table 4 column (3) and column (5). However, similar results can be obtained using any of the other specifications.
} 
of a FA. However, when the bank's primary supervisor is the Fed, the stance of monetary policy is also an important determinant. In particular, when the federal funds rate increases from its sample mean of $5.56 \%$ to $6.56 \%$, the probability of the Fed issuing a FA against a troubled institution decreases by approximately $22 \%$.

The last two columns of Table 7 report the percentage change in the probability of a FA when one of the regressors changes by 1-standard deviation from its sample mean. Using 1-standard deviation instead of a 1-percentage change allows a comparison of marginal effects that takes into account the likelihood of observing a certain change in each one of the regressors (i.e., a given change might be too little for one variable and too much for another). Most results are qualitatively the same. In particular, the most important determinants of the probability of a FA are the same, but their marginal effects are higher because there is a lot of bank heterogeneity in the sample. It should be noted, however, that the marginal effects of $R E L / L, C \& I / L, O R E O / L$, and $L A / A$ are much higher than before. Finally, after taking into account how much the federal funds rate varied during the sample period, the marginal effect of the coefficient of interest increases considerably from $22 \%$ to approximately $33 \%$; the standard deviation of the federal funds rate during the sample period is $1.85 .^{28}$

The bottom portion of Table 7 contains information regarding the model's goodness of fit. The model does a pretty good job in distinguishing FA quarters and non-FA quarters. Based on a threshold value equal to the proportion of observations equal to 1 , the model predicts a FA when there was no FA for only $16 \%$ of the observations, while it predicts no FA when there was a FA for only $12 \%$ of the observations. ${ }^{29}$

\footnotetext{
${ }^{28}$ The corresponding marginal effects from a logit model are $17 \%$ and $26 \%$, respectively.

${ }^{29}$ Measuring goodness of fit is problematic for probit models. A measure that is widely used in the literature is the percentage of outcome that is correctly predicted, based on a 50 percent threshold (i.e., predicted $=1$, if probability $>50$ percent; predicted $=0$, if probability $<50$ percent). However, if the percentage of observations that is equal to 1 is substantially less than 50 percent, as it is in this case, a 50 percent threshold can be particularly inappropriate. Cramer (1999) shows that a more appropriate threshold is the actual proportion of observations in that sample that equals 1.
} 


\section{Conclusions}

This paper examines whether and how monetary policy responsibilities affect the central bank's role as a bank supervisor. The methodology and the data employed improve upon previous studies in at least two ways. First, the paper escapes the usual criticisms of cross-sectional studies by limiting the analysis within a single country. The U.S. bank regulatory and supervisory system is ideal for such a study because of its segmented structure. Second, the construction and use of a unique dataset on formal regulatory actions allows a direct test of the behavior of bank supervisors.

The estimation results indicate that the Fed's monetary policy responsibilities do alter its bank supervisory role, at least for the United States during the sample period and for the particular aspect of bank supervision examined here. In particular, the stance of monetary policy affects the supervisory behavior of the Fed, but does not affect the behavior of the other two agencies. Since indicators of monetary policy matter only for the Fed, it is highly unlikely that they simply capture the effect of the business cycle. However, this possibility is formally tested in the sensitivity analysis by examining whether any of the "traditional" indicators of the business cycle affect bank supervision in the same way. It turns out that indicators of the business cycle, such as the growth rate of real GDP and the change in the national unemployment rate, matter for all three supervisors and not just for the Fed. Similar tests show that the results are not due to differences across the three groups of banks in their exposure to interest-rate risk.

The estimation results indicate that when the Fed tightens monetary policy, it becomes less strict in bank supervision. One explanation is that the Fed compensates banks for the extra pressure it puts on them, either because it views them as its constituency or because it is concerned about the micro-stability of the financial sector. In addition,

the sign on the estimated coefficient of monetary policy also indicates that the Fed is not 
using its role in bank supervision to reinforce the objectives of monetary policy (i.e., it does not try to get a "big bang for the buck").

Although, the analysis and discussion so far focuses exclusively on whether and how monetary policy alters the Fed's behavior in bank supervision, it is worth noting that this study is related to a much broader issue. In particular, over the years, major conflicts and disagreements emerged among the three agencies (e.g., Robertson 1966; FDIC, 1997). The reason for differences might be related to distinct incentives inherent in the structure and additional responsibilities of each agency. The OCC, the FDIC, and the Fed can be thought of as three economic agents maximizing different objective functions. While they are each responsible for promoting "safe and sound" banking practices, each agency has additional responsibilities that might affect its regulatory and supervisory role. This is not to say that these are necessarily "bad" objectives. As mentioned earlier, a problem would arise only if their institutional priorities differ from those of the society at large. However, more research is necessary before we are in a position to know whether the current structure creates suboptimal objectives for each one of these agencies. 


\section{Data Appendix}

The sample used for estimation is drawn from the set of all insured commercial and savings banks in the United States whose Call Reports show that they have positive total assets. However, consistent time-series variables are obtained after a series of adjustments that involve dealing with mergers, de novos, "shell" banks, and especially changes of definitions over time and/or across supervisors.

In order to avoid discontinuities in the surviving bank's indicators of financial performance, when two or more banks merge all banks involved in a merger are eliminated for the quarter that the merger occurs. ${ }^{30}$ Specifically, a dataset available from the Federal Reserve Bank of Chicago is used in order to identify all mergers and acquisitions that took place during the study's sample period. This dataset contains identification numbers for the surviving and nonsurviving entities, as well as the date when the merger became legally effective. However, this date may not fall within the quarter that the merging entities join their accounts (i.e., when banks start to report jointly).

The information contained in this dataset is combined with the Call Report Data to calculate the growth rate of the surviving bank's transactions deposits. Since this type of liability does not usually vary significantly from quarter to quarter, its growth rate is used to identify any unusual jump in the data. In particular, the growth rate of the transactions deposits is calculated for six quarters before and six quarters after the effective date of the merger. Moreover, the ratio of the surviving bank's transactions deposits over the nonsurviving bank's transactions deposits is calculated in order to have an indicator of the expected size of the jump. This ratio is dated at the nonsurviving bank's last reporting quarter. However, there are cases where the jump in the data is so small that it is not clear when the merger actually occurred. Since the objective of the exercise is to eliminate outliers, these cases are not really a problem.

\footnotetext{
${ }^{30}$ The surviving bank's balance sheet is the sum of its own balance sheet and of all the other banks involved in the merger.
} 
The first two years of de novo bank observations are also omitted, since their characteristics are not typical of a fully operational bank. Like all new ventures, true de novos start out with unusually high levels of capital (financed mainly through equity), low levels of core deposits, and an unseasoned and usually rapidly growing loan portfolio. The procedure employed to identify banks that are truly de novo can be described in two steps. In the first step, a set of possible de novo banks is created. This set includes any entity which reports data at time $t$, but does not report at time $t-1$. However, this set includes banks which are not necessarily de novo (i.e., new entities formed from pre-existing banks). Thus, in step two, banks that do not exhibit the characteristics of de novo banks are eliminated from the set of possible de novo banks (e.g., banks with positive nonperforming loans at their first reporting quarter or banks with positive dividends at some point during their first reporting year).

"Shell" banks are also dropped. "Shell" banks are banks which exist as a legal entity (and therefore are required to file call reports) but are not operational in the usual sense. These are usually banks with zero loans or with a small amount of loans that does not change significantly from quarter to quarter. More generally, banks with total loans less than $5 \%$ of their total assets are also eliminated in order to ensure a relatively homogeneous set of banks.

However, the most challenging part of the general effort to yield sensible time-series data is dealing with changes in definitions of variables over time. To cope with this problem, "Dictionary files" available from the Federal Reserve Bank of Chicago (at http://www.chicagofed.org/economicresearchanddata/data/bhcdatabase/dictionary.cfm) are used. These files provide detailed definitions for all variables contained in the Call Report Data, as well as information regarding changes in these definitions. Among all indicators of financial performance, the most complicated variable to construct is bank capital. However, it is also a key variable for regulatory intervention. Hence, all capital 
ratios used are constructed as to exactly equal the measure generated by each of the three supervisors at each point in time, due to the generous help of Peggy Gilligan at the Federal Reserve Bank of Boston.

\section{References}

[1] Bagehot, Walter. Lombard Street, Kegan, Paul \& Co., London, 1873.

[2] Barth, James R., Nolle, Daniel E., Phumiwasana, Triphon, and Glenn Yago. "A Cross-Country Analysis of the Bank Supervisory Framework and Bank Performance." Financial Markets, Institutions \& Instruments 12 (2003), 67-120.

[3] Berger, Allen N., Kashyap, Anil K., and Joseph M. Scalise. "The Transformation of the U.S. Banking Industry: What a Long Strange Trip It's Been.” Brookings Papers on Economic Activity 2 (1995), 55-201.

[4] Berger, Allen N., Kyle, Margaret, K., and Joseph M. Scalise. "Did U.S. Bank Supervisors Get Tougher During the Credit Crunch? Did They Get Easier During the Banking Boom? Did it Matter to Bank Lending?" in Prudential Supervision: What Works and What Doesn't?", edited by Frederic S. Mishkin, pp. 301-352. Chicago, Illinois: The University of Chicago Press, 2001.

[5] Berger, Allen N., and Gregory F. Udell. "Did Risk-Based Capital Requirements Allocate Bank Credit and Caused a 'Credit Crunch' in the United States?" Journal of Money, Credit and Banking 26 (1994), 585-628.

[6] Bernanke, Ben S. "Comment" in Prudential Supervision: What Works and What Doesn't?", edited by Frederic S. Mishkin, pp. 293-97. Chicago, Illinois: The University of Chicago Press, 2001. 
[7] Bernanke, Ben S., and Mark Gertler. "Inside the Black Box: The Credit Channel of Monetary Policy Transmission." Journal of Economic Perspectives 9 (1995), 27-48.

[8] Bernanke, Ben S., and Cara Lown. "The Credit Crunch." Brookings Papers on Economic Activity 2 (1991), 205-239.

[9] Bernanke, Ben S., and Ilian Mihov. "Measuring Monetary Policy." The Quarterly Journal of Economics 113 (1998), 869-902.

[10] Briault, Clive. "The Rationale for a Single National Financial Services Regulator." Financial Services Authority Occasional Paper, series 2 (1999).

[11] Campello, Murillo. "Internal Capital Markets in Financial Conglomerates: Evidence from Small Bank Responses to Monetary Policy." Journal of Finance 57 (2002), $2773-2805$.

[12] Cramer, J. S. "Predictive Performance of the Binary Logit Model in Unbalanced Samples," Journal of the Royal Statistical Society, D, 48, 1999, 85-94.

[13] Federal Deposit Insurance Corporation. "The Banking Crises of the 1980s and Early 1990s: Summary and Implications." Chapter 1 in History of the Eighties-Lessons for the Future 1 (1997), 3-85.

[14] Di Noia Carmine, and Giorgio Di Giorgio. "Should Bank Supervision and Monetary Policy Tasks be Given to Different Agencies?" International Finance 2 (1999), 361378.

[15] Feldman, Ron J., Kim, Jan, Miller, Preston J. and Jason E. Scmidt. "Are Bank Supervisory Data Useful for Macroeconomic Forecasts?" Contributions to Macroeconomics 3 (2003), No. 1, Article 3. 
[16] Goodhart, Charles A. E., and Dirk Schoenmaker. "Institutional Separation between Supervisory and Monetary Agencies." Giornale degli Economisti e Annali di Economia 9-12 (1992), 353-439.

[17] Goodhart, Charles A. E., and Dirk Schoenmaker. "Should the Functions of Monetary Policy and Banking Supervision be Separated?" Oxford Economic Papers 47 (1995), 539-560.

[18] Hancock, Diana L., and James A. Wilcox. "Bank Capital Shocks: Dynamic Effects on Securities, Loans and Capital." Journal of Banking and Finance 19 (1995), 661677.

[19] Haubrich, Joseph G. "Combining Bank Supervision and Monetary Policy." Federal Reserve Bank of Cleveland, Economic Commentary November (1996).

[20] Heller, Robert H. "Prudential Supervision and Monetary Policy." in Essays in Honor of Jacques Polak, edited by Frenkel Jacob A., and Morris Goldstein, pp. 269-281, Washington DC: International Monetary Fund, 1991.

[21] Hubbard, Glenn R. "Is there a 'Credit Channel' for Monetary Policy?" Federal Reserve Bank of St. Louis Review May/June (1995), 63-77.

[22] Kashyap, Anil K., Stein, Jeremy C., and David W. Wilcox. "Monetary Policy and Credit Conditions: Evidence from the Composition of External Finance." American Economic Review 83 (1993), 78-98.

[23] Kashyap, Anil K., and Jeremy C. Stein. "What Do a Million Banks Say About the Transmission of Monetary Policy?" American Economic Review 90 (2000), 407-428. 
[24] Llewellyn, David T. "Introduction: the Institutional Structure of Regulatory Agencies" in How Countries Supervise Their Banks, Insurers, and Securities Markets, edited by Courtis, Neil, London: Central Bank Publications, 1999.

[25] Peek, Joe, and Eric S. Rosengren. "Bank Regulation and the Credit Crunch." Journal of Banking and Finance 19 (1995), 679-692.

[26] Peek, Joe, and Eric S. Rosengren. "Derivatives Activity at Troubled Banks." Journal of Financial Services Research, 12 (1997), 287-302.

[27] Peek, Joe, Rosengren, Eric S., and Geoffrey M. B. Tootell. "Is Bank Supervision Central to Central Banking?" Quarterly Journal of Economics 114 (1999), 629-653.

[28] Robertson, J. L. "Federal Regulation of Banking: a Plea for Unification." Law of Contemporary Problems 31 (1966), 673-695.

[29] Simons, Katerina. "Interest Rate Derivatives and Asset-Liability Management by Commercial Banks." New England Economic Review January/February (1995), 1728.

[30] Stein, Jeremy C. "An Adverse Selection Model of Bank Asset and Liability Management with Implications for the Transmission of Monetary Policy." Rand Journal of Economics, 29 (1998), 466-486.

[31] Vittas, Dimitri. Thrift Regulation in the United Kingdom and the United States, a Historical Perspective. Washington, World Bank, September, 1992. 
Table 1: Formal Actions Imposed During the Period 1990-1998*

\begin{tabular}{lccccccccccc}
\hline \hline \multicolumn{10}{c}{ Number of Formal Actions } \\
\hline & 1990 & 1991 & 1992 & 1993 & 1994 & 1995 & 1996 & 1997 & 1998 & Total \\
& 264 & 352 & 198 & 58 & 44 & 14 & 18 & 30 & 35 & 1013 \\
\hline \multicolumn{8}{c}{ The Percentage of Banks under Supervisor $i$ that are under a Formal Action at time $t$} \\
\hline \multicolumn{1}{c}{1990} & 1991 & 1992 & 1993 & 1994 & 1995 & 1996 & 1997 & 1998 & \\
OCC & 3.82 & 4.82 & 3.27 & .95 & .55 & .32 & .33 & .74 & .91 & \\
FED & .85 & 3.02 & 1.84 & .57 & .89 & .84 & .31 & .94 & .42 & .16 \\
FDIC & 1.51 & 2.17 & 1.10 & .35 & .30 & .09 & .10 & .15 & .16 & \\
\hline \hline
\end{tabular}

* Includes cease and desist orders and written agreements. 
Table 2: Definitions and Notation

\begin{tabular}{|c|c|c|}
\hline Category & Definition & Notation \\
\hline \multirow[t]{3}{*}{ Capital Adequacy } & Tier 1 Capital to Average Assets & Tier1/AvA \\
\hline & Tier 1 Capital to Risk-Weighted Average Assets & Tier1/RWA \\
\hline & Total Capital to Risk-Weighted Assets & TC/RWA \\
\hline \multirow[t]{7}{*}{ Asset Quality } & Real Estate Loans to Total Loans & $\mathrm{REL} / \mathrm{L}$ \\
\hline & Commercial \& Industrial Loans to Total Loans & $\mathrm{C} \& \mathrm{I} / \mathrm{L}$ \\
\hline & Other Real Estate Owned to Total Loans & OREO/L \\
\hline & Nonperforming Loans to Total Loans & NPL/L \\
\hline & Loan Loss Reserves to Total Assets & $\mathrm{LLR} / \mathrm{A}$ \\
\hline & Gap for up to 3 months to Total Assets & GAP1/A \\
\hline & Gap for 3 months to 1 year to Total Assets & GAP2/A \\
\hline \multirow[t]{2}{*}{ Earnings Ratios } & Return on Average Assets & $\mathrm{R} / \mathrm{AvA}$ \\
\hline & Loan Loss Provisions to Average Assets & LLP/AvA \\
\hline \multirow[t]{2}{*}{ Asset Liquidity } & Liquid Assets to Total Assets & $\mathrm{LA} / \mathrm{A}$ \\
\hline & Brokered Deposits to Total Assets & $\mathrm{BKD} / \mathrm{A}$ \\
\hline \multirow[t]{2}{*}{ Off-Balance Sheet } & Interest-Rate Derivatives to Total Assets & Derivatives/A \\
\hline & Non-Interest Income to Total Interest Income & NII/TII \\
\hline Bank Size & Log of Total Assets & LogAssets \\
\hline \multirow[t]{3}{*}{ Supervisor Specific } & Dummy variable for banks supervised by the OCC & OCC \\
\hline & Dummy variable for banks supervised by the FDIC & FDIC \\
\hline & Dummy variable for banks supervised by the Fed & FED \\
\hline Monetary Policy & Federal Funds Rate & FFunds \\
\hline \multirow[t]{3}{*}{ Macro Indicators } & Annual Growth Rate of Real GDP & $G(\operatorname{RGDP})_{t, t-4}$ \\
\hline & State Unempl. Rate - National Unempl. Rate & Sune-Nune \\
\hline & Change of the National Rate of Unemployment & $\Delta$ Nune $_{t, t-4}$ \\
\hline
\end{tabular}


Table 3: Average Risk-Profile of Three Groups of Banks During 1990-98

\begin{tabular}{|c|c|c|c|c|}
\hline & & No FA & Start FA & End FA \\
\hline \multirow[t]{3}{*}{ Capital Adequacy } & Tier1/AvA & $\begin{array}{c}9.65 \\
(3.48)\end{array}$ & $\begin{array}{c}6.65 \\
(3.03)\end{array}$ & $\begin{array}{c}8.73 \\
(9.06)\end{array}$ \\
\hline & Tier1/RWA & $\begin{array}{l}15.82 \\
(9.76)\end{array}$ & $\begin{array}{l}10.26 \\
(6.20)\end{array}$ & $\begin{array}{l}13.79 \\
(9.82)\end{array}$ \\
\hline & $\mathrm{TC} / \mathrm{RWA}$ & $\begin{array}{c}18.47 \\
(12.48)\end{array}$ & $\begin{array}{l}12.98 \\
(7.77)\end{array}$ & $\begin{array}{l}15.45 \\
(10.02)\end{array}$ \\
\hline \multirow[t]{7}{*}{ Asset Quality } & $\mathrm{REL} / \mathrm{L}$ & $\begin{array}{c}3.25 \\
(5.25)\end{array}$ & $\begin{array}{c}6.11 \\
(8.07)\end{array}$ & $\begin{array}{c}3.56 \\
(4.91)\end{array}$ \\
\hline & $\mathrm{C} \& \mathrm{I} / \mathrm{L}$ & $\begin{array}{c}16.55 \\
(11.64)\end{array}$ & $\begin{array}{c}22.22 \\
(14.87)\end{array}$ & $\begin{array}{c}18.70 \\
(12.95)\end{array}$ \\
\hline & OREO/L & $\begin{array}{c}0.66 \\
(2.13)\end{array}$ & $\begin{array}{c}3.11 \\
(4.10)\end{array}$ & $\begin{array}{l}2.00 \\
(2.71)\end{array}$ \\
\hline & $\mathrm{NPL} / \mathrm{L}$ & $\begin{array}{c}1.41 \\
(1.89)\end{array}$ & $\begin{array}{c}4.94 \\
(3.97)\end{array}$ & $\begin{array}{l}2.63 \\
(2.62)\end{array}$ \\
\hline & $\mathrm{LLR} / \mathrm{A}$ & $\begin{array}{c}0.89 \\
(0.52)\end{array}$ & $\begin{array}{c}1.68 \\
(1.06)\end{array}$ & $\begin{array}{c}1.44 \\
(0.85)\end{array}$ \\
\hline & GAP1/A & $\begin{array}{l}19.78 \\
(12.05)\end{array}$ & $\begin{array}{c}26.12 \\
(14.75)\end{array}$ & $\begin{array}{c}23.50 \\
(13.17)\end{array}$ \\
\hline & GAP2/A & $\begin{array}{c}15.21 \\
(10.29)\end{array}$ & $\begin{array}{c}11.13 \\
(10.09)\end{array}$ & $\begin{array}{c}13.95 \\
(10.53)\end{array}$ \\
\hline \multirow[t]{2}{*}{ Earnings Ratios } & $\mathrm{R} / \mathrm{AvA}$ & $\begin{array}{c}1.09 \\
(1.33)\end{array}$ & $\begin{array}{l}-2.18 \\
(4.76)\end{array}$ & $\begin{array}{c}0.95 \\
(1.88)\end{array}$ \\
\hline & $\mathrm{LLP} / \mathrm{AvA}$ & $\begin{array}{c}0.29 \\
(0.90)\end{array}$ & $\begin{array}{c}3.00 \\
(4.55)\end{array}$ & $\begin{array}{c}0.17 \\
(1.30)\end{array}$ \\
\hline \multirow[t]{2}{*}{ Asset Liquidity } & $\mathrm{LA} / \mathrm{A}$ & $\begin{array}{c}28.47 \\
(15.16)\end{array}$ & $\begin{array}{c}20.85 \\
(12.44)\end{array}$ & $\begin{array}{c}27.94 \\
(13.46)\end{array}$ \\
\hline & $\mathrm{BKD} / \mathrm{A}$ & $\begin{array}{c}0.32 \\
(2.16)\end{array}$ & $\begin{array}{c}1.15 \\
(3.80)\end{array}$ & $\begin{array}{c}0.33 \\
(13.45)\end{array}$ \\
\hline \multirow[t]{2}{*}{ Off-Balance Sheet } & Derivatives/A & $\begin{array}{c}1.35 \\
(26.14)\end{array}$ & $\begin{array}{c}3.23 \\
(63.01)\end{array}$ & $\begin{array}{c}3.46 \\
(43.26)\end{array}$ \\
\hline & NII/TII & $\begin{array}{c}3.83 \\
(41.89)\end{array}$ & $\begin{array}{c}5.35 \\
(7.33)\end{array}$ & $\begin{array}{c}6.09 \\
(9.07)\end{array}$ \\
\hline Bank Size & LogAssets & $\begin{array}{l}11.12 \\
(1.25)\end{array}$ & $\begin{array}{l}11.21 \\
(1.32)\end{array}$ & $\begin{array}{l}11.07 \\
(1.38)\end{array}$ \\
\hline
\end{tabular}

Notes: No FA: banks not under a FA; Start FA: banks at the time of the exam that resulted in FA; End FA: banks at the end of the termination of the FA. Standard deviations in parenthesis. 
Table 4: The Effect of Monetary Policy on the Probability of Getting a FA

\begin{tabular}{|c|c|c|c|c|c|c|}
\hline & Regressors & $(1)$ & $(2)$ & $(3)$ & (4) & $(5)$ \\
\hline \multirow[t]{3}{*}{ Capital Adequacy } & Tier1/AvA & $\begin{array}{l}-.0727^{* * *} \\
(.011)\end{array}$ & $\begin{array}{l}-.0824^{* * *} \\
(.0099)\end{array}$ & $\begin{array}{c}-.0820^{* * *} \\
(.0099)\end{array}$ & $\begin{array}{c}-.0776^{* * *} \\
(.0103)\end{array}$ & $\begin{array}{l}-.1011^{* * *} \\
(.0084)\end{array}$ \\
\hline & $\Delta(\text { Tier } 1 / A v A)_{t, t-4}$ & $\begin{array}{l}-.0124^{* * *} \\
\quad(.005)\end{array}$ & $\begin{array}{c}-.0119^{* *} \\
(.0051)\end{array}$ & $\begin{array}{c}-.0119^{* *} \\
(.0051)\end{array}$ & $\begin{array}{c}-.0122^{* *} \\
(.0049)\end{array}$ & $\begin{array}{l}-.0113^{* * *} \\
(.0021)\end{array}$ \\
\hline & Tier1/RWA & $\begin{array}{l}.0001 \\
(.0034)\end{array}$ & $\begin{array}{l}-.0031 \\
(.0023)\end{array}$ & $\begin{array}{l}.0031 \\
(.0023)\end{array}$ & $\begin{array}{l}.0020 \\
(.0028)\end{array}$ & $\begin{array}{l}.0035 \\
(.0022)\end{array}$ \\
\hline \multirow[t]{7}{*}{ Asset Quality } & $\mathrm{REL} / \mathrm{L}$ & $\begin{array}{c}.0081^{* * *} \\
(.0020)\end{array}$ & $\begin{array}{c}.0095^{* * *} \\
(.0020)\end{array}$ & $\begin{array}{c}.0096^{* * *} \\
(.0020)\end{array}$ & $\begin{array}{c}.0094^{* * *} \\
(.0020)\end{array}$ & $\begin{array}{c}.0086^{* * *} \\
(.0019)\end{array}$ \\
\hline & $\mathrm{C} \& \mathrm{I} / \mathrm{L}$ & $\begin{array}{c}.0037^{* * *} \\
(.0012)\end{array}$ & $\begin{array}{c}.0042^{* * *} \\
(.0012)\end{array}$ & $\begin{array}{c}.0042^{* * *} \\
(.0012)\end{array}$ & $\begin{array}{c}.0039^{* * *} \\
(.0012)\end{array}$ & $\begin{array}{c}.0046^{* * *} \\
(.0010)\end{array}$ \\
\hline & OREO/L & $\begin{array}{c}.0273^{* * *} \\
(.0034)\end{array}$ & $\begin{array}{c}.0280^{* * *} \\
(.0034)\end{array}$ & $\begin{array}{c}.0279^{* * *} \\
(.0034)\end{array}$ & $\begin{array}{c}.0268^{* * *} \\
(.0034)\end{array}$ & $\begin{array}{c}.0145^{* * *} \\
(.0038)\end{array}$ \\
\hline & $\mathrm{NPL} / \mathrm{L}$ & $\begin{array}{c}.0662^{* * *} \\
(.0054)\end{array}$ & $\begin{array}{c}.0669^{* * *} \\
(.0054)\end{array}$ & $\begin{array}{c}.0669^{* * *} \\
(.0054)\end{array}$ & $\begin{array}{c}.0663^{* * *} \\
(.0054)\end{array}$ & $\begin{array}{c}.0599^{* * *} \\
(.0048)\end{array}$ \\
\hline & LLR/A & $\begin{array}{l}.0085 \\
(.0230)\end{array}$ & $\begin{array}{l}.0076 \\
(.0233)\end{array}$ & $\begin{array}{l}.0070 \\
(.232)\end{array}$ & $\begin{array}{l}.0079 \\
(.0231)\end{array}$ & $\begin{array}{l}.0235 \\
(.0204)\end{array}$ \\
\hline & GAP1/A & $\begin{array}{l}.0008 \\
(.0014)\end{array}$ & $\begin{array}{l}.0005 \\
(.0014)\end{array}$ & $\begin{array}{l}.0006 \\
(.0014)\end{array}$ & $\begin{array}{l}.0007 \\
(.0014)\end{array}$ & \\
\hline & GAP2/A & $\begin{array}{l}-.0010 \\
(.0017)\end{array}$ & $\begin{array}{l}-.0016 \\
(.0017)\end{array}$ & $\begin{array}{l}-.0016 \\
(.0017)\end{array}$ & $\begin{array}{l}-.0015 \\
(.0017)\end{array}$ & \\
\hline \multirow[t]{2}{*}{ Earning Ratios } & $\mathrm{R} / \mathrm{AvA}$ & $\begin{aligned}-.0287^{* * *} & (.0102)\end{aligned}$ & $\begin{array}{c}-.0276^{* *} \\
(.011)\end{array}$ & $\begin{array}{c}-.0278^{* *} \\
(.0109)\end{array}$ & $\begin{aligned}-.0288^{* * *} & (.0105)\end{aligned}$ & $\begin{array}{c}-.0224^{* *} \\
(.0094)\end{array}$ \\
\hline & LLP/AvA & $\begin{array}{c}.0562^{* * *} \\
(.0146)\end{array}$ & $\begin{array}{c}.0560^{* * *} \\
(.0155)\end{array}$ & $\begin{array}{c}.0559^{* * *} \\
(.0155)\end{array}$ & $\begin{array}{c}.0547^{* * *} \\
(.0151)\end{array}$ & $\begin{array}{c}.0564^{* * *} \\
(.0126)\end{array}$ \\
\hline \multirow[t]{2}{*}{ Liquidity } & $\mathrm{LA} / \mathrm{A}$ & $\begin{array}{c}-.0086^{* * *} \\
(.0014)\end{array}$ & $\begin{array}{c}-.0089^{* * *} \\
(.0014)\end{array}$ & $\begin{array}{c}-.0089^{* * *} \\
(.0014)\end{array}$ & $\begin{array}{c}-.0089^{* * *} \\
(.0014)\end{array}$ & $\begin{array}{c}-.0089^{* * *} \\
(.0012)\end{array}$ \\
\hline & $\mathrm{BKD} / \mathrm{A}$ & $\begin{array}{l}.0030 \\
(.0051)\end{array}$ & $\begin{array}{l}.0038 \\
(.0049)\end{array}$ & $\begin{array}{l}.0038 \\
(.0049)\end{array}$ & $\begin{array}{l}.0039 \\
(.0050)\end{array}$ & $\begin{array}{c}.0081^{* * *} \\
(.0030)\end{array}$ \\
\hline \multirow[t]{2}{*}{ Off-Balance Sheet } & Derivatives/A & $\begin{array}{c}.0010^{* * *} \\
(.0004)\end{array}$ & $\begin{array}{c}.0010^{* * *} \\
(.0003)\end{array}$ & $\begin{array}{l}.0009^{* *} \\
(.0003)\end{array}$ & $\begin{array}{c}.0009^{* * *} \\
(.0003)\end{array}$ & $\begin{array}{c}.0008^{* * *} \\
(.0003)\end{array}$ \\
\hline & $\mathrm{NII} / \mathrm{TII}$ & $\begin{array}{l}.0026^{*} \\
(.0014)\end{array}$ & $\begin{array}{l}.0016 \\
(.0017)\end{array}$ & $\begin{array}{l}.0015 \\
(.0015)\end{array}$ & $\begin{array}{l}.0021 \\
(.0015)\end{array}$ & $\begin{array}{l}.0001^{* * *} \\
(.00002)\end{array}$ \\
\hline Bank Size & LogAssets & $\begin{array}{c}-.113^{* * *} \\
(.0132)\end{array}$ & $\begin{array}{c}-.1164^{* * *} \\
(.0133)\end{array}$ & $\begin{array}{c}-.1163^{* * *} \\
(.0133)\end{array}$ & $\begin{array}{l}-.1155^{* * *} \\
(.0133)\end{array}$ & $\begin{array}{l}-.1216^{* * *} \\
(.0117)\end{array}$ \\
\hline \multirow[t]{2}{*}{ Supervisor Specific } & $\mathrm{OCC}$ & $\begin{array}{l}.2337^{* * *} \\
(.0557)\end{array}$ & $\begin{array}{c}.2417^{* * *} \\
(.0556)\end{array}$ & $\begin{array}{l}-.1302 \\
(.1542)\end{array}$ & $\begin{array}{l}-.1406 \\
(.1545)\end{array}$ & $\begin{array}{l}-.1647 \\
(.1539)\end{array}$ \\
\hline & FDIC & $\begin{array}{l}-.1822^{* * *} \\
(.0572)\end{array}$ & $\begin{array}{l}-.1734^{* * *} \\
(.0571)\end{array}$ & $\begin{array}{c}-.5495^{* * *} \\
(.1582)\end{array}$ & $\begin{array}{l}-.5511^{* * *} \\
(.1588)\end{array}$ & $\begin{array}{l}-.5638^{* * *} \\
(.1563)\end{array}$ \\
\hline \multirow[t]{4}{*}{ Monetary Policy } & $(\text { FFunds })_{t-1}$ & & $\begin{array}{l}-.0098 \\
(.0092)\end{array}$ & & & \\
\hline & $\mathrm{FED} \times(\text { FFunds })_{t-1}$ & & & $\begin{array}{c}-.0728^{* * *} \\
(.0252)\end{array}$ & $\begin{array}{c}-.0709^{* * *} \\
(.0251)\end{array}$ & $\begin{array}{c}-.0757^{* * *} \\
(.0253)\end{array}$ \\
\hline & FDIC $\times(\text { FFunds })_{t-1}$ & & & $\begin{array}{l}-.0040 \\
(.0134)\end{array}$ & $\begin{array}{l}-.0026 \\
(.0134)\end{array}$ & $\begin{array}{l}-.0064 \\
(.0130)\end{array}$ \\
\hline & $\mathrm{OCC} \times(\text { FFunds })_{t-1}$ & & & $\begin{array}{l}-.0048 \\
(.0119)\end{array}$ & $\begin{array}{l}-.0023 \\
(.0120)\end{array}$ & $\begin{array}{l}-.0059 \\
(.0119)\end{array}$ \\
\hline \multirow[t]{5}{*}{ Macro Indicators } & $\mathrm{G}(\mathrm{RGDP})_{t-1, t-4}$ & & $\begin{array}{l}-.0910^{* * *} \\
(.0084)\end{array}$ & $\begin{array}{c}-.0920^{* * *} \\
(.0084)\end{array}$ & & $\begin{array}{l}-.0992^{* * *} \\
(.0074)\end{array}$ \\
\hline & $(\text { Sune }-N u n e)_{t-1}$ & & $\begin{array}{c}.0549^{* * *} \\
(.0126)\end{array}$ & $\begin{array}{c}.0549^{* * *} \\
(.0126)\end{array}$ & $\begin{array}{c}.0590^{* * *} \\
(.0127)\end{array}$ & $\begin{array}{c}.0606^{* * *} \\
(.0118)\end{array}$ \\
\hline & $\Delta$ Nune $_{t-1, t-4}$ & & & & $\begin{array}{c}.3058^{* * *} \\
(.0248)\end{array}$ & \\
\hline & Observations & 244,559 & 244,559 & 244,559 & 244,559 & 360,725 \\
\hline & Pseudo $\mathrm{R}^{2}$ & .2822 & 0.2742 & 0.2748 & 0.2782 & 0.2786 \\
\hline
\end{tabular}

Notes: $* * *, * *$, and $*$ denote significance at the $1 \%, 5 \%$, and $10 \%$ levels, respectively. Robust standard errors in parenthesis. Regional dummies are included in all specifications. Quarterly dummies are included only in column (1). 
Table 5: Business Cycle and Interest-Rate Risk

\begin{tabular}{|c|c|c|c|c|c|c|}
\hline & Regressors & (1) & $(2)$ & $(3)$ & $(4)$ & $(5)$ \\
\hline \multirow[t]{3}{*}{ Capital Adequacy } & Tier1/AvA & $\begin{array}{c}-.0825^{* * *} \\
(.0099)\end{array}$ & $\begin{array}{c}-.0782^{* * *} \\
(.0102)\end{array}$ & $\begin{array}{c}-.0822^{* * *} \\
(.0099)\end{array}$ & $\begin{array}{c}-.0823^{* * *} \\
(.0099)\end{array}$ & $\begin{array}{c}-.0824^{* * *} \\
(.0099)\end{array}$ \\
\hline & $\Delta\left(\text { Tier } 1 / A_{v A}\right)_{t, t-4}$ & $\begin{array}{l}-.0119^{* *} \\
(.0051)\end{array}$ & $\begin{array}{c}-.0123^{* *} \\
(.0048)\end{array}$ & $\begin{array}{c}-.0120^{* *} \\
(.0051)\end{array}$ & $\begin{array}{c}-.0119^{* *} \\
(.0051)\end{array}$ & $\begin{array}{c}-.0121^{* *} \\
(.0051)\end{array}$ \\
\hline & Tier1/RWA & $\begin{array}{c}.0034 \\
(.0023)\end{array}$ & $\begin{array}{l}.0021 \\
(.0028)\end{array}$ & $\begin{array}{l}.0030 \\
(.0023)\end{array}$ & $\begin{array}{l}.0031 \\
(.0024)\end{array}$ & $\begin{array}{l}.0032 \\
(.0023)\end{array}$ \\
\hline \multirow[t]{7}{*}{ Asset Quality } & $\mathrm{REL} / \mathrm{L}$ & $\begin{array}{c}.0096^{* * *} \\
(.0020)\end{array}$ & $\begin{array}{c}.0094^{* * *} \\
(.0020)\end{array}$ & $\begin{array}{c}.0093^{* * *} \\
(.0020)\end{array}$ & $\begin{array}{c}.0095^{* * *} \\
(.0020)\end{array}$ & $\begin{array}{c}.0092^{* * *} \\
(.0020)\end{array}$ \\
\hline & $\mathrm{C} \& \mathrm{I} / \mathrm{L}$ & $\begin{array}{c}.0042^{* * *} \\
(.0012)\end{array}$ & $\begin{array}{c}.0040^{* * *} \\
(.0012)\end{array}$ & $\begin{array}{c}.0041^{* * *} \\
(.0012)\end{array}$ & $\begin{array}{c}.0042^{* * *} \\
(.0012)\end{array}$ & $\begin{array}{c}.0042^{* * *} \\
(.0012)\end{array}$ \\
\hline & $\mathrm{OREO} / \mathrm{L}$ & $\begin{array}{c}.0279^{* * *} \\
(.0034)\end{array}$ & $\begin{array}{c}.0268^{* * *} \\
(.0034)\end{array}$ & $\begin{array}{c}.0281^{* * *} \\
(.0034)\end{array}$ & $\begin{array}{c}.0281^{* * *} \\
(.0034)\end{array}$ & $\begin{array}{c}.0279^{* * *} \\
(.0034)\end{array}$ \\
\hline & $\mathrm{NPL} / \mathrm{L}$ & $\begin{array}{c}.0670^{* * *} \\
(.0054)\end{array}$ & $\begin{array}{c}.0664^{* * *} \\
(.0053)\end{array}$ & $\begin{array}{c}.0667^{* * *} \\
(.0054)\end{array}$ & $\begin{array}{c}.0667^{* * *} \\
(.0054)\end{array}$ & $\begin{array}{c}.0668^{* * *} \\
(.0054)\end{array}$ \\
\hline & $\mathrm{LLR} / \mathrm{A}$ & $\begin{array}{l}.0067 \\
(.0233)\end{array}$ & $\begin{array}{l}.0069 \\
(.0232)\end{array}$ & $\begin{array}{l}.0076 \\
(.0234)\end{array}$ & $\begin{array}{l}.0079 \\
(.0235)\end{array}$ & $\begin{array}{l}.0100 \\
(.0235)\end{array}$ \\
\hline & GAP1/A & $\begin{array}{l}.0006 \\
(.0014)\end{array}$ & $\begin{array}{l}.0007 \\
(.0014)\end{array}$ & & $\begin{array}{l}.0005 \\
(.0014)\end{array}$ & $\begin{array}{l}.0005 \\
(.0014)\end{array}$ \\
\hline & GAP2/A & $\begin{array}{l}-.0016 \\
(.0017)\end{array}$ & $\begin{array}{l}-.0014 \\
(.0017)\end{array}$ & $\begin{array}{l}-.0015 \\
(.0017)\end{array}$ & & $\begin{array}{l}-.0016 \\
(.0017)\end{array}$ \\
\hline \multirow[t]{2}{*}{ Earning Ratios } & $\mathrm{R} / \mathrm{AvA}$ & $\begin{array}{c}-.0277^{* *} \\
(.0109)\end{array}$ & $\begin{array}{c}-.0289^{* * *} \\
(.0105)\end{array}$ & $\begin{array}{c}-.0273^{* *} \\
(.0109)\end{array}$ & $\begin{array}{c}-.0274^{* *} \\
(.0110)\end{array}$ & $\begin{array}{c}-.0273^{* *} \\
(.0111)\end{array}$ \\
\hline & LLP/AvA & $\begin{array}{c}.0559^{* * *} \\
(.0155)\end{array}$ & $\begin{array}{c}.0546^{* * *} \\
(.0152)\end{array}$ & $\begin{array}{c}.0565^{* * *} \\
(.0155)\end{array}$ & $\begin{array}{c}.0559^{* * *} \\
(.0155)\end{array}$ & $\begin{array}{c}.0561^{* * *} \\
(.0156)\end{array}$ \\
\hline \multirow[t]{2}{*}{ Liquidity } & $\mathrm{LA} / \mathrm{A}$ & $\begin{array}{c}-.0089^{* * *} \\
(.0014)\end{array}$ & $\begin{array}{c}-.0089^{* * *} \\
(.0014)\end{array}$ & $\begin{array}{c}-.0089^{* * *} \\
(.0014)\end{array}$ & $\begin{array}{c}-.0089^{* * *} \\
(.0014)\end{array}$ & $\begin{array}{c}-.0090^{* * *} \\
(.0014)\end{array}$ \\
\hline & $\mathrm{BKD} / \mathrm{A}$ & $\begin{array}{l}.0038 \\
(.0049)\end{array}$ & $\begin{array}{l}.0040 \\
(.0050)\end{array}$ & $\begin{array}{l}.0036 \\
(.0050)\end{array}$ & $\begin{array}{l}.0039 \\
(.0049)\end{array}$ & $\begin{array}{l}.0047 \\
(.0050)\end{array}$ \\
\hline \multirow[t]{2}{*}{ Off-Balance Sheet } & Derivatives/A & $\begin{array}{l}.0009^{* *} \\
(.0004)\end{array}$ & $\begin{array}{c}.0009^{* * *} \\
(.0003)\end{array}$ & $\begin{array}{c}0009^{* * *} \\
(.0004)\end{array}$ & $\begin{array}{c}0009^{* * *} \\
(.0004)\end{array}$ & \\
\hline & $\mathrm{NII} / \mathrm{TII}$ & $\begin{array}{l}.0015 \\
(.0017)\end{array}$ & $\begin{array}{l}.0020 \\
(.0016)\end{array}$ & $\begin{array}{c}0017 \\
(.0017)\end{array}$ & $\begin{array}{l}.0016 \\
(.0017)\end{array}$ & $\begin{array}{c}0018 \\
(.0016)\end{array}$ \\
\hline Bank Size & LogAssets & $\begin{array}{l}-.1162^{* * *} \\
(.0133)\end{array}$ & $\begin{array}{l}-.1152^{* * *} \\
(.0133)\end{array}$ & $\begin{array}{c}-.1160^{* * *} \\
(.0134)\end{array}$ & $\begin{array}{l}-.1172^{* * *} \\
(.0134)\end{array}$ & $\begin{array}{c}-.1071^{* * *} \\
(.0134)\end{array}$ \\
\hline \multirow[t]{11}{*}{ Supervisor Specific } & $\mathrm{OCC}$ & $\begin{array}{c}.2694^{* * *} \\
(.0757)\end{array}$ & $\begin{array}{c}.1834^{* * *} \\
(.0669)\end{array}$ & $\begin{array}{c}.3852^{* * *} \\
(.1259)\end{array}$ & $\begin{array}{c}.2909^{* * *} \\
(.0818)\end{array}$ & $\begin{array}{l}.2504^{* * *} \\
(.0560)\end{array}$ \\
\hline & FDIC & $\begin{array}{c}-.1685^{* *} \\
(.0783)\end{array}$ & $\begin{array}{c}-.1868^{* * *} \\
(.0682)\end{array}$ & $\begin{array}{l}-.1198^{* * *} \\
(.1286)\end{array}$ & $\begin{array}{l}-.0998 \\
(.0829)\end{array}$ & $\begin{array}{c}-.1705^{* * *} \\
(.0574)\end{array}$ \\
\hline & $\mathrm{FED} \times \mathrm{G}(\mathrm{RGDP})_{t-1}$ & $\begin{array}{l}-.0806^{* * *} \\
(.0310)\end{array}$ & & & & \\
\hline & $\mathrm{FDIC} \times \mathrm{G}(\mathrm{RGDP})_{t-1}$ & $\begin{array}{c}-.0833^{* * *} \\
(.0129)\end{array}$ & & & & \\
\hline & $\mathrm{OCC} \times \mathrm{G}(\mathrm{RGDP})_{t-1}$ & $\begin{array}{c}-.0990^{* * *} \\
(.0110)\end{array}$ & & & & \\
\hline & $\mathrm{FED} \times \Delta$ Nune $_{t-1, t-4}$ & & $\begin{array}{l}.2287^{* *} \\
(.0927)\end{array}$ & & & \\
\hline & $\mathrm{FDIC} \times \Delta$ Nune $_{t-1, t-4}$ & & $\begin{array}{l}.2578^{* * *} \\
(.0384)\end{array}$ & & & \\
\hline & OCC $\times \Delta$ Nune $_{t-1, t-4}$ & & $\begin{array}{l}.2561^{* * *} \\
(.0381)\end{array}$ & & & \\
\hline & $\mathrm{FED} \times \mathrm{GAP} 1 / \mathrm{A}$ & & & $\begin{array}{l}.0042 \\
(.0039)\end{array}$ & & \\
\hline & $\mathrm{FDIC} \times \mathrm{GAP} 1 / \mathrm{A}$ & & & $\begin{array}{l}.0022 \\
(.0018)\end{array}$ & & \\
\hline & $\mathrm{OCC} \times \mathrm{GAP} 1 / \mathrm{A}$ & & & $\begin{array}{l}-.0015 \\
(.0018)\end{array}$ & & \\
\hline
\end{tabular}


Table 5: Business Cycle and Interest-Rate Risk (Continued from previous page)

\begin{tabular}{|c|c|c|c|c|c|c|}
\hline & Regressors & $(1)$ & $(2)$ & $(3)$ & (4) & $(5)$ \\
\hline & $\mathrm{FED} \times \mathrm{GAP} 2 / \mathrm{A}$ & & & & $\begin{array}{l}.0036 \\
(.0099)\end{array}$ & \\
\hline & $\mathrm{FDIC} \times \mathrm{GAP} 2 / \mathrm{A}$ & & & & $\begin{array}{l}-.0032 \\
(.0022)\end{array}$ & \\
\hline & $\mathrm{OCC} \times \mathrm{GAP} 2 / \mathrm{A}$ & & & & $\begin{array}{l}-.0012 \\
(.0021)\end{array}$ & \\
\hline & FED $\times$ Derivatives $/ A$ & & & & & $\begin{array}{c}.0095^{* * *} \\
(.0003)\end{array}$ \\
\hline & FDIC $\times$ Derivatives $/ A$ & & & & & $\begin{array}{l}.0013^{*} \\
(.0008)\end{array}$ \\
\hline & OCC $\times$ Derivatives $/ A$ & & & & & $\begin{array}{c}-.0057^{*} \\
(.0031)\end{array}$ \\
\hline Monetary Policy & FFunds $_{t-1}$ & $\begin{array}{l}-.0098 \\
(.0092)\end{array}$ & $\begin{array}{l}-.0078 \\
(.0093)\end{array}$ & $\begin{array}{l}-.0095 \\
(.0092)\end{array}$ & $\begin{array}{l}-.0096 \\
(.0093)\end{array}$ & $\begin{array}{l}-.0099 \\
(.0092)\end{array}$ \\
\hline \multirow[t]{4}{*}{ Business Cycle } & $\mathrm{G}(\mathrm{RGDP})_{t-1}$ & & & $\begin{array}{c}-.0909^{* * *} \\
(.0084)\end{array}$ & $\begin{array}{c}-.0911^{* * *} \\
(.0084)\end{array}$ & $\begin{aligned}-.0914^{* * *} & (.0084)\end{aligned}$ \\
\hline & $(\text { Sune -Nune })_{t-1}$ & $\begin{array}{c}.0553^{* * *} \\
(.0127)\end{array}$ & $\begin{array}{c}.0560^{* * *} \\
(.0127)\end{array}$ & $\begin{array}{c}.0545^{* * *} \\
(.0126)\end{array}$ & $\begin{array}{c}.0548^{* * *} \\
(.0126)\end{array}$ & $\begin{array}{c}.0542^{* * *} \\
(.0126)\end{array}$ \\
\hline & Observations & 244,559 & 244,559 & 244,559 & 244,559 & 244,559 \\
\hline & Pseudo $\mathrm{R}^{2}$ & .2743 & .2781 & .2746 & .2744 & .2749 \\
\hline
\end{tabular}

Notes: $* * *, * *$, and $*$ denote significance at the $1 \%, 5 \%$, and $10 \%$ levels, respectively. Robust standard errors in parenthesis. Regional dummies are included in all specifications. 
Table 6: Differential Effect of the Business Cycle Across Supervisors

\begin{tabular}{|c|c|c|c|c|}
\hline & Regressors & FED & FDIC & $\mathrm{OCC}$ \\
\hline \multirow[t]{3}{*}{ Capital Adequacy } & Tier1/AvA & $\begin{array}{c}-.0924^{* * *} \\
(.0303)\end{array}$ & $\begin{array}{c}-.0947^{* * *} \\
(.0201)\end{array}$ & $\begin{array}{c}.0741^{* * *} \\
(.0121)\end{array}$ \\
\hline & $\Delta(\operatorname{Tier} 1 / \operatorname{AvA})_{t, t-4}$ & $\begin{array}{c}-.0356^{* * *} \\
(.0130)\end{array}$ & $\begin{array}{c}-.0237^{* * *} \\
(.0057)\end{array}$ & $\begin{array}{c}-.0085^{* *} \\
(.0045)\end{array}$ \\
\hline & Tier1/RWA & $\begin{array}{c}-.0011^{*} \\
(.0006)\end{array}$ & $\begin{array}{l}-.0087 \\
(.0056)\end{array}$ & $\begin{array}{c}-.0079^{* * *} \\
(.0018)\end{array}$ \\
\hline \multirow[t]{7}{*}{ Asset Quality } & REL/L & $\begin{array}{l}.0102^{*} \\
(.0061)\end{array}$ & $\begin{array}{l}.0053^{*} \\
(.0028)\end{array}$ & $\begin{array}{c}.0085^{* * *} \\
(.0032)\end{array}$ \\
\hline & $\mathrm{C} \& \mathrm{I} / \mathrm{L}$ & $\begin{array}{l}.0015 \\
(.0034)\end{array}$ & $\begin{array}{c}.0024 \\
(.0020)\end{array}$ & $\begin{array}{c}.0061^{* * *} \\
(.0017)\end{array}$ \\
\hline & OREO/L & $\begin{array}{l}.0186^{*} \\
(.0109)\end{array}$ & $\begin{array}{c}.0328^{* * *} \\
(.0046)\end{array}$ & $\begin{array}{c}.0333^{* * *} \\
(.0070)\end{array}$ \\
\hline & NPL/L & $\begin{array}{c}.1165^{* * *} \\
(.0182)\end{array}$ & $\begin{array}{c}.0602^{* * *} \\
(.0089)\end{array}$ & $\begin{array}{c}.0645^{* * *} \\
(.0074)\end{array}$ \\
\hline & $\mathrm{LLR} / \mathrm{A}$ & $\begin{array}{l}-.0698 \\
(.0865)\end{array}$ & $\begin{array}{c}.0577 \\
(.0366)\end{array}$ & $\begin{array}{c}.0007 \\
(.0367)\end{array}$ \\
\hline & GAP1/A & $\begin{array}{l}.0083^{*} \\
(.0045)\end{array}$ & $\begin{array}{l}.0010 \\
(.0021)\end{array}$ & $\begin{array}{l}-.0013 \\
(.0021)\end{array}$ \\
\hline & GAP2/A & $\begin{array}{c}.0042 \\
(.0059)\end{array}$ & $\begin{array}{l}-.0003 \\
(.0026)\end{array}$ & $\begin{array}{l}-.0014 \\
(.0024)\end{array}$ \\
\hline \multirow[t]{2}{*}{ Earning Ratios } & $\mathrm{R} / \mathrm{AvA}$ & $\begin{array}{l}.0589^{*} \\
(.0390)\end{array}$ & $\begin{array}{l}-.0223 \\
(.0158)\end{array}$ & $\begin{array}{c}-.0322^{* * *} \\
(.0111)\end{array}$ \\
\hline & $\mathrm{LLP} / \mathrm{AvA}$ & $\begin{array}{c}.1105^{* * *} \\
(.0403)\end{array}$ & $\begin{array}{l}.0437^{* *} \\
(.0216)\end{array}$ & $\begin{array}{c}.0866^{* * *} \\
(.0185)\end{array}$ \\
\hline \multirow[t]{2}{*}{ Liquidity } & $\mathrm{LA} / \mathrm{A}$ & $\begin{array}{c}-.0119^{* *} \\
(.0060)\end{array}$ & $\begin{array}{c}-.0083^{* * *} \\
(.0023)\end{array}$ & $\begin{array}{c}-.0082^{* * *} \\
(.0018)\end{array}$ \\
\hline & $\mathrm{BKD} / \mathrm{A}$ & $\begin{array}{l}.0203 \\
(.0179)\end{array}$ & $\begin{array}{l}-.0005 \\
(.0089)\end{array}$ & $\begin{array}{c}.0073 \\
(.0062)\end{array}$ \\
\hline \multirow[t]{2}{*}{ Off-Balance Sheet } & Derivatives/A & $\begin{array}{c}.0014^{* * *} \\
(.0042)\end{array}$ & $\begin{array}{l}.0016^{* *} \\
(.0008)\end{array}$ & $\begin{array}{c}-.0057^{*} \\
(.0033)\end{array}$ \\
\hline & NII/TII & $\begin{array}{l}-.0069 \\
(.0100)\end{array}$ & $\begin{array}{l}.0009 \\
(.0027)\end{array}$ & $\begin{array}{l}.0027 \\
(.0028)\end{array}$ \\
\hline Bank Size & LogAssets & $\begin{array}{c}-.0865^{* * *} \\
(.0298)\end{array}$ & $\begin{array}{c}-.1302^{* * *} \\
(.0229)\end{array}$ & $\begin{array}{c}-.1050^{* * *} \\
(.0196)\end{array}$ \\
\hline Monetary Policy & $(\text { FFunds })_{t-1}$ & $\begin{array}{c}-.0806^{* * *} \\
(.0284)\end{array}$ & $\begin{array}{l}.0156 \\
(.0153)\end{array}$ & $\begin{array}{l}-.0111 \\
(.0128)\end{array}$ \\
\hline \multirow[t]{4}{*}{ Business Cycle } & $(\mathrm{GRGDP})_{t-1}$ & $\begin{array}{c}-.0986^{* * *} \\
(.0295)\end{array}$ & $\begin{array}{c}-.0742^{* * *} \\
(.0138)\end{array}$ & $\begin{array}{c}-.1009^{* * *} \\
(.0112)\end{array}$ \\
\hline & $(\text { Sune -Nune })_{t-1}$ & $\begin{array}{c}.0601^{* * *} \\
(.0415)\end{array}$ & $\begin{array}{c}.0827^{* * *} \\
(.0200)\end{array}$ & $\begin{array}{l}.0123 \\
(.0186)\end{array}$ \\
\hline & Observations & 20,670 & 150,006 & 73,883 \\
\hline & Pseudo $\mathrm{R}^{2}$ & 0.2708 & 0.3265 & 0.2698 \\
\hline
\end{tabular}

Notes: $* * *, * *$, and $*$ denote significance at the $1 \%, 5 \%$, and $10 \%$ levels respectively. Robust standard errors in parenthesis. Regional dummies are included in all specifications. 
Table 7: Economic Significance and Goodness of Fit

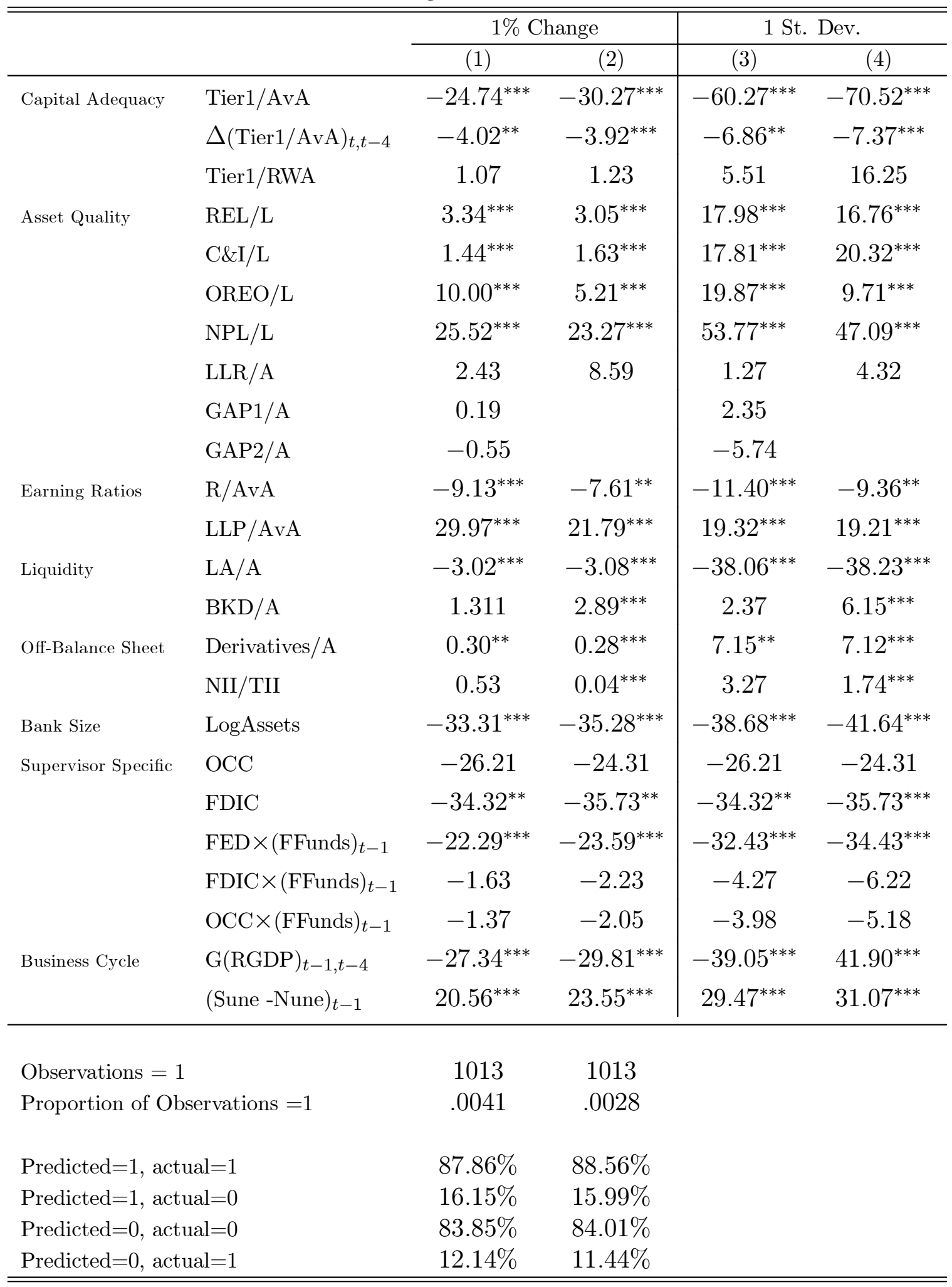

Notes: ${ }^{* * *}, * *$, and $*$ denote significance at the $1 \%, 5 \%$, and $10 \%$ levels respectively. Regional dummy variables are included in all specifications. For the dummy variables OCC and FDIC, the coefficient represents the change in the probability for one unit change (i.e., from 0 to 1 ). 